\title{
Going for Gold: An Analysis of Morningstar Analyst Ratings
}

\author{
Will J. Armstrong * \\ Egemen Genc ${ }^{\dagger}$ \\ Marno Verbeek
}

October 18, 2013

\begin{abstract}
In September 2011 Morningstar launched its qualitative forward-looking analyst ratings to supplement its widely followed backward-looking star ratings. This new system is designed to convey information about a mutual fund's future performance using a five-tier scale: Gold, Silver, Bronze, Neutral, and Negative. We examine both the investor response to analyst rating initiations and the out-of-sample performance of newly rated funds. We find that investors respond positively to Gold and Silver rated funds relative to other rated funds. We find little evidence that the new rating system identifies funds that outperform peer funds at horizons of up to 6 months. Overall, it appears that rating initiations influence investor allocation decisions, but it remains unclear whether the ratings provide valuable information regarding long-term, out-of-sample performance.
\end{abstract}

\footnotetext{
*Rawls College of Business, Texas Tech University, Lubbock TX 79409, USA.; E-mail: will.armstrong@ @ttu.edu.

${ }^{\dagger}$ Rotterdam School of Management, Erasmus University, Rotterdam 3062 PA, The Netherlands.;E-mail: egenc@rsm.nl

"Rotterdam School of Management, Erasmus University, Rotterdam 3062 PA, The Netherlands.;E-mail: mverbeek@rsm.nl
} 


\section{Introduction}

In September 2011, Morningstar launched a new analyst rating that summarizes their analyst's outlook for each rated fund using a five-tier scale. The assigned rating reflects the analyst's expectation of the fund's future performance relative to its peers. Gold, Silver, and Bronze rated funds are expected to outperform their peers on a risk-adjusted basis over a full market cycle of at least 5 years. The difference between these ratings reflects the analyst's level of conviction with respect to this expected superior performance. Gold ratings are assigned to funds in which analysts are most confident about their predictions. Neutral ratings are assigned to funds where the analyst does not have a strong positive or negative opinion regarding the fund's future performance, while Negative ratings are assigned to inferior funds that are likely to underperform 1 Gold, Silver, and Bronze rated funds are classified as Recommended funds, while funds with Neutral and Negative ratings are classified as Not Recommended.

The analyst ratings are intended to supplement the popular star ratings, which rank funds based on their risk-adjusted realized return relative to their peers.2 ${ }^{2}$ Since their introduction in the mid1980s, investors have widely relied on star ratings to select funds. Indeed, the star rating is so influential that over $90 \%$ of new money is invested into funds with top star ratings, while funds with low star ratings lose money 3 Accordingly, many funds advertise their star ratings to attract new investors and numerous academic papers document the importance of star ratings in investor allocation decisions (e.g., Del Guercio and Tkac, 2002, 2008, Bergstresser and Poterba, 2002). However, the star rating is frequently criticized for being a purely quantitative and backwardlooking measure, which may be of limited use to investors as past superior performance is no

\footnotetext{
${ }^{1}$ Morningstar Analyst Rating for Funds Methodology Document, Morningstar Fund Research Group, November 15,2011

${ }^{2}$ In order to calculate star ratings, Morningstar first rates each fund over the trailing three, five, and ten year periods resulting in up to three ratings depending on the age of the fund. The funds overall summary rating is the weighted average of its available ratings. Blume (1998), Blake and Morey (2000), and Morey (2002) give a detailed description of the rating methodology. In June 2002, Morningstar made major changes to its methodology and started using smaller peer groups and new risk-adjusted performance measures. See Del Guercio and Tkac (2008), and Morningstar Ratings for Funds Factsheet (2008) for more details.

3’Morningstar Edges Toward One-Year Ratings,” The Wall Street Journal, April 5, 1996
} 
indication of future superior performance (e.g., Carhart, 1997) $]^{4}$ The literature suggests that star ratings are weak predictors of future performance ${ }^{5}$

While the star rating ranks funds solely on past achievements, the analyst rating is a qualitative, forward-looking measure that identifies which funds are expected to outperform their peers over a full market cycle. The analyst rating is based on an analyst's evaluation of the fund across five pillars, only one of which reflects past performance. The remaining pillars are price (fees and trading costs), quality of investment team, parent organization, and investment process. Thus, the analyst ratings have the potential to provide a more comprehensive evaluation of the fund's prospects as they incorporate information from multiple dimensions, including both quantitative and qualitative elements.

This paper provides a first look at Morningstar's analyst ratings. We first examine the investors' response to ratings initiations. Given that Morningstar is an independent, well-known, and credible source of investment advice, analyst ratings may represent a new opinion valued by the market. Consequently, this new information may affect investor allocation decisions leading to a fund flow response to rating initiations. To understand the flow response to rating initiations, we compute the change in fund flows between the periods prior to and after the rating initiation, and test whether the flow response for Gold, Silver, and Bronze rated funds is higher than the flow response for Not Recommended funds. Del Guercio and Tkac (2008) show that investors can make allocation decisions at different intervals or may not follow funds frequently. Accordingly, we test the flow response over various windows ranging from one to six months after ratings are awarded in order to allow for a delayed response.

We find that flow reactions to funds with initial ratings of Gold or Silver are significantly higher than flow reactions to funds receiving Not Recommended ratings. Specifically, the flow reaction to Gold rating initiations is $4.2 \%$ higher than the flow reaction to Not Recommended rating initiations

\footnotetext{
4"Now Morningstar ratings look forward and back", Chicago Tribune, January 2012

${ }^{5}$ Among others, Blake and Morey (2000) and Morey (2005) find that (prior to the 2002 change) higher star ratings are weak predictors of future superior performance, while funds with low star ratings underperform their peers. Gottesman and Morey (2006) argue that after changes in June 2002, the rating system can better predict future performance. Contradictory to this result, Kraussl and Sandelowsky (2007) find that the predictive power of star ratings does not beat a random walk even after Morningstar made changes to their rating system in 2002.
} 
over a six month window resulting in a difference in cumulative flows of $\$ 285$ million (based on an average rated fund in our sample, $\$ 6,811.9$ million * 0.0419). Similarly, the flow reaction to Silver rating initiations is $3.43 \%$ higher than the flow reaction to Not Recommended ratings. Our results are robust to controls for a broad range of fund characteristics.

The flow response to Silver rating initiations is generally not statistically different from the flow reaction to Gold rated funds. However, we are unable to find a positive flow response to Bronze rating initiations. It might be because Morningstar previously grouped funds with positive outlook as recommended in their analyst picks rating system. Following the introduction of the new analyst ratings, some previously recommended funds received a Bronze rating while others received Gold and Silver ratings. Investors might view Bronze funds as inferior with respect to Gold and Silver rated funds given their higher level of analyst conviction. In additional tests, we extract the residual (unexpected) flows from realized flows by purging the influence of past fund flows and returns. Similar to the results with raw flows, the flow reaction of Gold and Silver funds is significantly higher when we use residual flows as our dependent variable.

We want to ensure that our results are not due to differences in fund characteristics that are not captured in our regression specification, non-linearity in the relationship between flows and our independent variables or some unobserved characteristics. To address these concerns, we repeat the tests using abnormal flows computed as the difference between the rated fund flows and flows of the best matched unrated funds where funds are matched across multiple dimensions. A propensity score matching algorithm is used to identify the unrated fund that is the best match for each rated fund. Match-adjustment also helps to control for temporal differences in aggregate flows and helps correct for the non-random distribution of ratings initiations ${ }^{6}$ We find that Gold rated funds have a flow reaction of $12 \%$ higher than Not Recommended funds over a six month window, while the flow reaction is approximately $9.5 \%$ for Silver rated funds. Again, we do not find any significant positive flow reaction to Bronze funds. We obtain similar results for abnormal flows when we replace match-adjusted raw flows with match-adjusted residual flows. Overall, our results suggest

\footnotetext{
${ }^{6}$ Per their November 2011 press release, Morningstar's plan was to roll out analyst rating initiations to the funds that "garnered the most investor attention and assets, collectively representing more than 75 percent of industry assets."
} 
that investors view Gold and Silver rating initiations as positive news and react positively to these ratings by flocking to those funds at a higher rate than lower rated funds.

Given that investors have access to both analyst ratings and star ratings, an interesting question is how the two rating systems interact. For instance, how do investors respond if the two ratings send different or similar signals to investors about the quality of a fund? To investigate this issue, we first divide funds into two groups: High Star and Low Star. The High Star group includes funds with 4 or 5 stars, while the Low Star group includes the remainder. We repeat our tests for both groups. Our results show that positive analyst ratings influence flows only within the High Star group. Similarly, we divide funds into two groups based on their analyst ratings: Recommended vs Not Recommended. Recommended funds are the ones with Gold, Silver, and Bronze ratings, while Not Recommended funds are the funds with Neutral or Negative ratings. We then regress the flow response onto a High Star dummy, which takes the value of 1 if the fund is 4 or 5 star, 0 otherwise. We find that star ratings affect fund flows only within the set of Recommended funds. Together, our results suggest that investors jointly consider both sources of information when making investment decisions. Investors appear to refrain from investing in funds where the two ratings provide conflicting signals, and flock to funds that receive positive ratings from both rating systems.

Next, we examine whether the forward-looking and qualitative features captured in the new analyst ratings can predict out-of-sample performance. Analysts spend a considerable amount of time researching funds and the fund market, and thus should have more information about funds than an average fund investor. Morningstar's Analyst Rating system attempts to identify funds that will outperform their peers over the long term. While the literature generally does not support superior performance persistence over longer horizons (e.g., Carhart, 1997, Bollen and Busse, 2005), there is some evidence that relative out-of-sample performance is correlated with certain fund characteristics (e.g., Cremers and Petajisto, 2009, Kacperczyk and Seru, 2007 ). To examine whether analyst ratings are able to predict out-of-sample performance we examine cumulative returns in the one, three, and six month periods following each rating initiation. 
Using realized and risk-adjusted returns, we find that Gold, Silver and Bronze rated funds do not significantly outperform Not Recommended funds at any horizon. At some horizons, Not Recommended funds have risk-adjusted returns that are significantly higher than Gold and Bronze rated funds. We also analyze out-of-sample performance in rated funds relative to the best matched unrated funds in order to correct for differences in fund characteristics between the rating categories that are not captured by the included control variables or the style, time, or star group fixed effects. After match-adjustment, we find no evidence that Gold and Silver rated funds have higher riskadjusted returns than those for Not Recommended funds at any horizon. There is also no evidence that Gold rated funds outperform Silver or Bronze rated funds.

We extend our analysis to examine whether investors could earn a significantly higher return by investing in each of the Recommended rating categories. Each month we form equally-weighted calendar time portfolios for each rating category. These portfolios are rebalanced monthly. We find that investors who invest in portfolios of Recommended funds do not earn higher returns than those who invest in Not Recommended funds. Morningstar argues that the ratings are long-term in nature and are designed to identify funds that will outperform their peers over a full market cycle. While data limitations prevent us from drawing a conclusion regarding the long-term performance, our results suggest that analyst ratings do not have predictive power in the short-term (over our sample period).

Our paper makes several contributions to the current literature. Several papers have shown that stock prices react to analysts' recommendations. $7^{7}$ Brown, Wie, and Wermers (2009) find that fund managers are prudent to follow analyst recommendations. Yet, there is no evidence demonstrating how analyst-based fund recommendations affect fund investor decisions. Mutual funds offer a unique way of examining investor decisions via fund flows rather than inferring them from asset prices as in equity markets. Using analyst ratings from Morningstar, we provide an important first step toward filling this gap.

\footnotetext{
${ }^{7}$ See, among others, Barber and Loeffler (1993), Bjerring, Lakonishok, and Vermaelen (1983), Copeland and Mayers (1982), Desai and Jain (1995), Bolster and Trahan (2009), Barber, Lehavy, McNicols, and Trueman (2001), Womack (1996), Diether, Malloy, and Scherbina (2002)
} 
The fund industry and academic researchers have often criticized the research and marketing of mutual funds, which is traditionally based on backward-looking measures such as past performance. The main criticism is that backward-looking measures are fundamentally achievement tests and paint a too narrow picture of a fund's likelihood of outperforming their peers in the future. Examining the out-of-sample performance of analyst rated funds offers a unique opportunity to evaluate forward-looking measures. The lack of any significant out-ofsample performance of Gold and Silver rated funds relative to their peers provides a first look at some new evidence in the ongoing debate regarding performance predictability in the fund market.

Our results also contribute to the literature that investigates the determinants of fund flows, which are important for at least two reasons. First, fund managers generally receive a fixed percentage of assets under management as a fee. Hence, fund flows are the mechanism by which investors influence managerial incentives (Chevalier and Ellison, 1997). Second, fund flows indirectly affect asset prices because capital flows into and out of mutual funds determine the demand for stocks in the funds' portfolios (Coval and Stafford, 2007, Wermers, 2004). Therefore, providing a possible link between analyst ratings and subsequent fund flows advances our understanding of managerial incentives and the formation of security prices.

From a practical perspective, our results are important for investors seeking to maximize the return on their investments and fund managers trying to maximize assets under management. Given the proliferation of investment advice from various sources, investors should be interested in knowing the reliability and value of analyst ratings. The impact of analyst ratings on future fund flows may incentivize fund managers to improve in the key areas that affect their fund's analyst ratings.

The paper proceeds as follows: Section 1 provides background on Morningstar's analyst ratings and describes the data. Section 2 examines the investor flow response to rating initiations. Section 3 examines the combined effect of analyst ratings and star ratings on investor flows. Section 4 examines out-of-sample performance, and Section 5 concludes. 


\section{Data}

\subsection{Background on Morningstar Analyst Ratings}

Morningstar began assigning analyst ratings to funds in September 2011. The rating process starts with the analyst conducting a review of the fund that is intended to develop an initial view regarding future performance of the fund and determine the key areas of concerns. Prospectuses, shareholder reports, questionnaires from the fund group, news regarding the fund, and performance data may be taken into consideration as a part of this research. This initial stage is followed by a series of interviews with the fund manager, executives of the parent company, risk managers, and traders. After these interviews and consultation with peers, the analyst prepares a report reviewing the fund across five dimensions, which Morningstar believe to be crucial for predicting future performance 8

People: The overall quality of a fund's investment team is assessed by considering experience, expertise, talent, stability, manager workload, information flow, and alignment of interest.

Process: The analyst seeks to understand the strength of the fund's investment strategy, the ability of management to execute the fund strategy successfully, whether the process is matched to manager's skill set and fund's resources, and the risks entailed in the process.

Parent: The parent company is evaluated based on key areas including stewardship, recruitment and retention of talent, risk and capacity management, regulator compliance, and organization strategy.

Price: Fund's expenses are analyzed to understand whether the fund offers a good value compared with similar funds sold through similar channels.

Performance: The analyst focuses on whether the manager adds value, the sources of performance, consistency of performance over time, risks taken, and the performance of the same managers in other present or previous accounts.

The analysts assigns a score of Positive, Negative or Neutral to each pillar, which forms the

\footnotetext{
8"Morningstar Analyst Ratings for Funds Methodology Document", Fund Research Group (November,2011)
} 
Pillar Scorecard of the fund. For instance, a fund may get a negative score on the people pillar because it lacks expertise, the research team is not sufficient or stable, or the manager does not have sufficient track record. The analyst then presents her assessment to a rating committee. If the committee agrees with her judgment in each area, the analyst assigns a final rating on a five-tier scale with three medals of Gold, Silver, and Bronze, a Neutral rating, and a Negative rating. The analyst does not simply tally up the pillars as each pillar has overlap with the others, but tries to synthesize the pillars and judge on how they work together. The rating is free to all fund customers, while the Pillar Scorecard and the corresponding analyst's report can be accessed with a subscriber fee. Funds with Gold, Silver, and Bronze ratings are medalist funds with Morningstar's positive assessment. The difference between these three ratings is based on the level of analyst conviction. For example, Morningstar describes a Gold rating as follows:

"To earn a Gold rating, a fund must distinguish itself across the five pillars that are the basis for our analysis. That is, a Gold rated fund should have a seasoned, talented, and successful manager or management team; a sound, thoughtful process that has been executed skillfully and consistently; a portfolio thats in harmony with the stated process and thats capable of delivering a reward that compensates investors for the risks it takes; reasonable expenses; and a strong parent organization that is focused on responsible stewardship of investor assets

A Bronze rated fund may not, on the other hand, have notable advantages across all five pillars, but still have an overall advantage that outweighs its disadvantages when compared to its peers. Morningstar does not have a strong positive or negative opinion about funds with Neutral ratings. An average fund in a category receives this rating as long as its fees gives it a competitive advantage. An unproven, but promising fund may also get a Neutral rating until Morningstar sees enough evidence of potential outperformance. Negative rated funds are the ones that, according Morningstar, possess at least one flaw that is likely to adversely affect the future performance such as high fees unstable management team etc. 


\subsection{Description of the Sample}

Morningstar Direct reports only the analyst ratings and dates given in the latest analyst report. The analyst report publication date is also the first date that the analyst rating becomes publicly available. For all rated funds as of December 2012, we first collect all historical analyst reports back to September 2011, which is first date the analyst ratings start. From these reports, we obtain all analyst ratings and the corresponding report dates for rated funds from September 2011 to December 2012. The median number of reports for a rated fund is one (mean $=1.6)$. We analyze rating initiations whereby the analyst evaluates the fund for the first time and assigns a rating. Using rating initiations allows us to use the longest return and flow time-series in our tests.

Monthly time-series of returns, total net assets, and fund categories for all rated and unrated funds are obtained from Morningstar Direct. We obtain other fund characteristics such as fees and loads from the CRSP Mutual Fund Database because Morningstar either reports them at yearly frequency (e.g., fees) or only reports the latest value (i.e loads) whereas CRSP has quarterly data. We limit our sample to funds in one of the Morningstar nine equity fund categories formed by the intersections of three size (Small, Mid-cap, Large) and three valuation (Value, Blend, Growth) categories. This filter removes bond, balanced, international, and sector funds from the sample. To remove index funds, we use the index fund field available in Morningstar. To account for potential incubation bias (Evans, 2010), we eliminate funds less than two years old and funds that have total net assets below five million dollars in the previous month.

Our sample contains 357 equity funds rated between September 2011 and December 2012. Even though Morningstar rates only $18 \%$ of the equity funds, the rated funds manage $72 \%$ of the total assets in our sample as of December 2012. Figure 1A shows the number of rated funds in each month, while Figure1B shows the distribution of ratings across investment categories. Out of 357 rated equity funds, $72 \%$ of funds have Gold, Silver, or Bronze ratings while $28 \%$ of funds garner Neutral and Negative ratings. The number of positive ratings is surprising given that a majority of funds underperform their benchmarks. Morningstar argues that analysts prioritize funds with the most investor interest, which tends to be high quality funds. Thus, the rating distributions might 
initially be skewed towards positive ratings. Further, most of the Gold rated funds are rated early in our sample period, while Bronze and Neutral ratings are assigned later in the sample period. Figure 1B shows that a large proportion of the rated funds are assigned to funds with style categories of Large Blend, Large Growth, and Large Value. In our empirical tests, we use time and style fixed effect in order to control for these timing and style effects.

Figure 2A demonstrates that the forward-looking analyst ratings are not perfectly correlated with the backward-looking star ratings. Funds with a four star rating are assigned the largest number of Gold, Silver, and Bronze ratings, while funds with three star ratings have the largest number of Neutral and Negative ratings. Del Guercio and Tkac (2008) find that star rating changes have a significant affect on flows and the flow response to star rating changes is not symmetric with respect to the direction and magnitude of the change. Figure $2 \mathrm{~B}$ demonstrates that within our sample there are 53 positive star rating changes and 63 negative star rating changes within six months of the rating initiation, with a relatively higher number of changes in the Bronze, Neutral, and Silver rating categories. To isolate the influence of analyst rating initiations on fund flows from the influence of star ratings and star ratings changes, we use star group fixed effects in our regressions. Star group is computed for each fund by combining the fund's star rating six month prior to rating initiation with its star rating at the rating initiation. For example, if six months prior to analyst rating initiation a fund has a star rating of three and the fund receives a star rating of four at the time of rating initiation, we assigned the fund to star group 34. Likewise, a fund moving from a four to a five star is assigned to star group 45. On the other hand, if this four star fund does not have a rating change at the time of rating initiation, the star group of the fund is 44 . The star group allows us to control for flow differences that are due to either the level of star ratings or changes in the star ratings.

Since Morningstar's decision to initiate coverage on a given fund is not random, there are differences in fund characteristics between rated and unrated funds. Table 1, Panel A demonstrates that the analyst rated funds belong to the largest families, are older, larger, and have lower expense ratios and lower turnover. Rated funds also have better risk-adjusted past performance over the 
previous 36 months compared to unrated funds even though performance is negative for both groups.

Table 1, Panel B shows there are also differences in fund characteristics between the analyst rating categories. We observe that Gold and Silver funds are larger than Bronze, Neutral, and Negative funds. Gold and Silver funds also have lower turnover and expense ratios, higher flows in the prior 12 months, and better risk-adjusted performance over the prior 36 months. These statistics suggest that controlling for style, time and star group fixed effects may not be sufficient to control the differences in fund characteristics among rated funds. In order to mitigate this concern, we take two actions. First, we explicitly control for a broad range of fund characteristics in our regressions. Second, we repeat each of our tests after adjusting the rated funds' flows and performance measures with the flow and performance measures of unrated funds that most closely match on a range of characteristics. We provide more details on match adjustment in Section 2.2.

\subsection{Measuring Fund Flows}

To measure the fund flows we use the standard flow measure in the literature

$$
\text { flow }_{i, t}=\frac{T N A_{i, t}-T N A_{i, t-1} *\left(1+R_{i, t}\right)}{T N A_{i, t-1}}
$$

where $T N A_{i, t}$ represents the total net assets of fund $i$ at the end of month $t$ and $R_{i, t}$ represents the monthly return of fund $i$ during month $t$. This definition reflects the growth rate of a fund due to new investments and assumes that all new investments occur at the end of the month. Elton, Gruber, and Blake (2001) show that the dates of fund mergers often differ from actual merger dates and this inaccuracy introduces a large number of errors in fund returns. Even though this bias in fund returns does not show a systematic pattern, it may lead to extreme values of flows. Therefore,

we trim flows if the change in total net assets is not between -0.5 and 2 as in Coval and Stafford (2007) in order to eliminate outliers.

Previous literature documents that capital flows are strongly related to past performance and flows (e.g., Sirri and Tufano, 1998, Coval and Stafford, 2007). Hence, in addition to raw flows, 
we also compute a residual fund flow measure similar to Coval and Stafford (2007). To compute residual flows, we perform Fama and MacBeth (1973) style regressions of fund flows on six months of past flows and returns.

$$
\text { flow }_{i, t}=a_{i, t}+\sum_{j=1}^{6} b_{i, j, t} * \text { flow }_{i, t-j}+\sum_{j=1}^{6} c_{i, j, t} * \text { return }_{i, t-j}
$$

In particular, each month from t-36 to t, we estimate a cross-sectional regression as in (2) and obtain the time-series average of estimated coefficients. We then calculate the resiudal flows as the fund flow minus the expected flow, which is the fitted value using the the time-series average of estiamted coefficients. This approach purges the effects of past returns and flows from our measure to isolate the effect of the rating event on fund flows. Further, this approach also nets out the affects of unobserved characteristics to the extent the characteristics are correlated with past flows (and returns). To demonstrate robustness, our analysis includes both raw and residual flows in each of the tests.

\section{Flow Response to Rating Initiations}

In this section we examine the investor response to analyst rating initiations that occur between September 2011 and December 2012. Section 2.1 provides details of our flow response measures, Section 2.2 provides details on our match-adjustment process, and Section 2.3 presents our empirical results.

\subsection{Measuring Flow Response}

To analyze flow response to rating initiations, we compare fund flows measured over the 1, 3, and 6 month post-event window to the corresponding values measured over the 1, 3, and 6 month windows preceding the event. Since there are very few funds assigned an initial rating of negative in our sample (see Figure 1A), we group Negative and Neutral rated funds into a Not Recommended category in our empirical tests. If investors respond positively to Gold, Silver, and 
Bronze ratings and negatively to Neutral and Negative ratings then we expect an increase in flows to funds with Gold, Silver, or Bronze ratings relative to Not Recommended funds. To test this we regress change in fund flows on Gold, Silver, and Bronze indicator variables according to the following specification:

$$
\Delta \text { flow }_{i,(t-k, t+k)}=\alpha+\beta_{\text {Gold }} * \text { Gold }_{i, t}+\beta_{\text {Silver }} * \text { Silver }_{i, t}+\beta_{\text {Bronze }} \text { Bronze }_{i, t}+\text { Controls }_{i, t}+\varepsilon_{i, t}(3)
$$

where $\Delta$ flow $_{i,(t-k, t+k)}$ represents the change in flow measured over 1, 3, and 6 months before and after the analyst rating is assigned and $\alpha$ represents the flow reaction for Not Recommended funds net of fixed effects. Gold is an indicator variable that takes the value of 1 if the fund is rated Gold, or 0 otherwise. Thus, the coefficient $\beta_{\text {Gold }}$ gives the incremental flow reaction for Gold rated funds relative to Not Recommended funds. Similarly, Silver and Bronze are corresponding indicators for Silver and Bronze rated funds.

We include time, style, and star group fixed effects in order to address several issues within our data sample, and to isolate the impact of analyst ratings from star changes. First, as discussed in Section 1, the distribution of ratings is not randomly distributed through time. Figure 1A shows that 45 of the 53 Gold ratings (85\%) are assigned in the first three months while only $24 \%$ of the non-Gold ratings are assigned by this time. Flow response to different ratings might be subject to a time effect particularly given that there is substantial variation in aggregate flows over our sample period. Second, Figure 1B demonstrates that a large percentage of initial ratings are assigned to funds investing in large capitalization stocks. Our time and style fixed effect aim to capture these differences. Lastly, we add star group indicator variables to control for the potential flow reaction due to changes in star ratings (Del Guercio and Tkac, 2007), and isolating the influence of analyst rating initiations from changes in star ratings.As discussed in Section 1, star group is computed for each fund by combining the funds star rating six month prior to the fund's analyst rating initiation and its star rating at the analyst rating initiation.

Previous research determines that fund flows are related to fund-specific characteristics (Sirri and Tufano (1997), Barber, Odean, and Zheng (2005) ). As discussed in Section 1, differences in fund characteristics among rated funds may impact our results. Thus, in addition to dummies, we 
control for various fund characteristics including fund and family total net assets, age of the fund, expense ratios, turnover, past returns, and return volatilities.

\subsection{Match-Adjustment}

Our tests compare the flow response to rated funds after adjusting for differences in fund characteristics as well as including time, style, and star group fixed effects. However, there may be additional flow-characteristic relationships that are not fully controlled for in our regressions. For example, there may be a non-linear relationship between flows and fund characteristics, relationships between fund flows and aggregate fund flows, or previously unidentified characteristics that may affect the rated funds flow independent of the analyst ratings.

We are especially concerned with the effect of Morningstars non-random process for selecting which funds would be rated first. For example, Figure 1A shows that most of the Gold assignments occur early in our sample, while Silver, Bronze, and Neutral ratings are spread more evenly across time. If the time effect influences each fund by the same amount, then the month indicator variables are sufficient to absorb the time effect. Given the previously discussed differences in fund characteristics, the time effect may not be constant across the rating categories suggesting that including time fixed effects may not fully control for the time effect (Peterson 2009).

To address these concerns, we compute a match-adjusted flow for each rated fund as the difference in flow between the rated fund and an unrated fund that is matched on a set of fund characteristics. Match-adjusted flow captures the abnormal flow that a rated fund gains relative to an unrated fund, which has otherwise similar characteristics to the rated fund. We argue that adjusting rated fund flows with its closest peer on multiple dimensions helps us to control for complex relationships between flows and fund characteristics than may not be captured in our regression specification. To the extent that a rated fund's flows are affected by fund characteristics not captured in our regression specification, the peer firm should be affected in a similar manner unless the flow response is due to the rating initiation. Match-adjustment also helps to net out the non-constant time effects (i.e. the impact of aggregate flows and market returns) under the 
assumption that peer funds are similarly affected by systematic market forces.

To identify unrated funds that are the best match for our rated funds, we employ a multinomial logistic regression model to estimate the probabilities used in a propensity score matching process 9 Each month we estimate cross-sectional regressions by regressing the initial rating type (5=Gold, $4=$ Silver, $3=$ Bronze, 2 -Neutral, $1=$ Negative, and $0=$ unrated) on a set of lagged fund characteristics that include net assets, firm net assets, age, expense ratio, turnover, 36-month Fama-French 3-factor alpha, and past 12 months fund flows. For each fund, the regression model produces a probability of being rated in each of the analyst rating categories.

We match each rated fund with the unrated fund (within the same style group) that has the probability of being rated in the rated fund's category that is closest to the probability assigned to the rated fund. For example, a large value fund assigned a Gold rating in November 2011 would be matched with the unrated large value fund that has the probability of being weighted as Gold that is closest to the probability assigned to the rated fund. We remove funds that are rated within the subsequent 6 months from the pool of potential matches to ensure that the matched fund's flows are not affected by a subsequent rating event.10

Figure 3 graphically demonstrates the quality of the matching process across eight fund characteristics. Each panel compares the distribution of the indicated fund characteristic for the rated funds with the distribution of the characteristic for the best matched, unrated funds. The distribution is very similar for the following six characteristics: Fund net assets, fund age, turnover, past 12-month return, past 12-month flow, and past 36-month alpha. The distribution of expense ratios for rated and matched funds is very similar with a small number of matched funds having relatively high expense ratios. The matched funds also have lower fund family next assets in the

\footnotetext{
${ }^{9}$ We chose the multinomial logistic regression model (MLRM) for our propensity score matching process for several reasons. First, Morningstar does not suggest that Gold rated funds will outperform Bronze rated funds, but rather they have a higher conviction. Second, after estimating the MLRM in a full-panel setting with month fixed effects (instead of monthly cross-sectional regressions used in the match process), we computed a Hausman test of independence of irrelevant alternatives which suggested that the IIA assumption is not violated (results support the null hypothesis of independence). Third, in untabulated results we replace the MLRM matching process with a matching process based on an ordered probit model and achieved similar results.

${ }^{10} \mathrm{We}$ also run the analysis without dropping funds rated over the subsequent 6 months and get quantitatively and qualitatively similar results.
} 
right tail of the distribution. This is because Morningstar chose to rollout the new analyst ratings by starting with the largest funds and fund families. Overall, these results suggest that our matching process meets our objective of identifying the unrated funds that are the closest match to the rated funds with respect to a broad range of fund characteristics.

\subsection{The Effects of Analyst Ratings on Investor Flows}

We now present our flow response results for analyst rating initiations that occur between September 2011 and December 2012. While the analyst rating system is relatively new, there are 357 ratings initiations that occur in this window which is sufficient to provide valuable insight regarding investors' response to this new rating system.

Table 2, Panel A shows the flow response to analyst rating initiations. The left portion of each panel examines relative differences in realized flows, while the right portion of each panel examines differences in residual flows. As discussed earlier, residual flows for each fund are computed to purge the influence of past returns and past flows on fund flows so that we can isolate the effects of rating initiations. Panel A shows that both realized flows and residual flows to Gold and Silver Funds are higher than flows to Not Recommended funds at a six month horizon. At the six month horizon, the Gold indicator variable has a coefficient estimate of .0419 $(t$-statistic $=1.83)$ when realized flows are used and $.0498(t$-statistic $=2.85)$ when residual flows are used. This suggests that Gold rated funds have an average six month change in fund flows that is between 4 and 5 percent higher than Not Recommended funds. This suggests that for the average rated fund with $\$ 6,811.9$ million in assets, a Gold rated fund receives roughly $\$ 285$ million (\$6,811.9 million * 0.0419) more in flows than Not Recommended funds in the following six months. The coefficient estimate for Gold rated funds is insignificant at one and three month windows suggesting that investor response to a rating initiation operates with a delay. This is consistent with the delayed reaction to star rating changes documented in the literature (e.g., Del Guercio and Tkac, 2008). Coefficient estimates for Silver rated funds are consistent with those for Gold rated funds. The flow reaction to Silver rating initiations is $3.43 \%$ higher than the flow 
reaction to Not Recommended ratings when realized flows are used and $2.81 \%$ higher than the flow response to Not Recommended funds when residual flows are used. A Wald test of this difference shows that the flow response to Silver ratings initiations is not statistically different from the flow reaction to Gold rated funds even though the magnitudes are smaller ( $p$-value $=0.721$ ). The results suggest that there is very little difference in changes of flows to Bronze funds than changes in flows to Not Recommended funds. Morningstar previously grouped funds with positive outlook as recommended in their analyst picks rating system. Following the introduction of the new analyst ratings, some previously recommended funds received a Bronze rating while others received Gold and Silver ratings. Investors might view Bronze funds as inferior with respect to Gold and Silver rated funds given their higher level of analyst conviction. As a result, investment decisions based on analyst ratings would lead investors to invest into Gold (or Silver) rated funds at the expense of other rated funds.

Including lagged fund characteristics as control variables strengthen our results. Table 2, Panel B shows that Gold rated funds $(5.43 \%, t$-statistic $=2.36)$ and Silver rated funds $(5.20 \%$, $t$-statistic $=2.60)$ hanve significantly higher flow responses than Not Recommended funds. The flow response to Bronze fund is not statistically significant albeit higher than the magnitude in regressions without controls. We obtain similar results when we replace realized flows with residual flows.

Table 3 presents the results when we extend our analysis using match-adjusted flows. Over the six month horizon, the coefficient on Gold is 0.115 ( $t$-statistic=2.56) in Panel A, and 0.137 $(t$-statistics $=2.99)$ in Panel B which includes controls for fund characteristics. This suggests that the difference in flows between Gold rated funds and their best-matched peers is approximately 12 to $14 \%$ higher that the difference between Not Recommended funds and their peers. Results are similar if we replace match-adjusted flows with match-adjusted residual flows. Silver also has significantly higher flows both in Panel A ( $t$-statistic=1.95), and when we control for fund characteristics in Panel B ( $t$-statistic=2.60). Again the results are robust to using residual flows. Consistent with Table 2, Bronze rated funds are not statistically different from Not Recommended 
funds at a six month horizon. Results of Wald tests confirm that Silver is not statistically different from Gold, while Bronze and Not Recommended are significantly lower than Gold at the six month horizon using both match-adjusted realized flow and match-adjusted residual flow.

Overall, our results show that in the six month window investors respond to Gold and Silver ratings positively by increasing their investment into these funds, while Bronze rating, albeit a positive rating according to Morningstar, do not observe a significant flow response.

\section{Investor Response to Analyst Ratings and Star Ratings}

In Section 2.1 we document that funds that receive positive analyst recommendations (especially Gold and Silver ratings) have higher 6-month change in flow than funds that receive Not Recommended ratings. Previous literature shows that funds with high star ratings- in particular 4 or 5 star rated funds- attract higher fund flows. (see for example, Ivkovic and Weisbenner (2006), Del Gurcio and Tkac (2002), and Bergstresser and Poterba (2002)). Given that investors have two ratings systems, an interesting question is how the introduction of the new analyst rating interacts with the previously documented star rating effect. Therefore, in this section, we analyze how the impact of analyst ratings changes within high star and low star groups and vice versa.

We start our analysis by dividing the funds in our sample into two groups: High Star and Low Star group. The High Star group includes the funds that have star rating of 4 or 5, while the Low Star groups includes the funds that have star ratings of 1, 2, or 3. We then replicate our regressions in Section 2 within each group. If investors simply replace the backward-looking star rating with the new forward-looking analyst rating, the effect of analyst ratings should be similar in both groups. However, a more reasonable expectation is that investors use the new analyst ratings in order to complement the star ratings. In this case, the analyst ratings should affect fund flows within high-star group, but we expect to observe no significant analyst ratings effect if this ratings contradicts the star ratings.

Table 4 presents the results of regressions within star rating groups. We find a strong, positive 
relationship between fund flow and funds that received recommended analyst ratings within the funds classified as High Star, and an insignificant relationship when the regression is run within the group of Low Star funds. This suggests that the Gold, Silver, and Bronze rated funds with star ratings of 4 or 5 receive significantly higher flow than Not Recommended funds with star ratings of 4 or 5 . However, there is no analyst effect when the star rating is less than 4 .

Next, we sort funds according to their analyst rating. We first divide our sample into two groups: Recommended and Not Recommended. Recommended funds are the funds that obtain Gold, Silver, or Bronze ratings from the analysts, while Not Recommended are the funds with Neutral or Negative ratings. We then examine the star effect by regressing fund flow on a High Star indicator variable within the subsets of funds that received Recommended or Not Recommended analyst ratings.

Table 5 presents the results of regressions within analyst rating groups. Similar to our results in Table 4, we find a strong conditional response to star ratings. There is a positive and significant fund flow to High Star funds, but only within the subset of funds that received Recommended analyst ratings. That is, there appears to be a strong, conditional relationship between between the analyst rating and star rating.

Overall, these results are consistent with investors viewing the new analyst rating as incremental information rather than subsuming the star rating. The positive flow relation in Table 4 suggests that within the set of funds with 4 or 5 stars, investor choose funds with Gold, Silver, and Bronze analyst ratings. This documents a strong analyst rating affect, but only in funds with high star ratings. The results in Table 5 suggest that within the funds that receive a Recommended rating, flows go to funds with star ratings of 4 or 5 . This shows that the star effect is strong, but only within funds that receive a Recommended rating. Together, the results suggest that the positive flow reaction we observe in the Section 2.1 is primarily driven by Recommended funds that have high stars. The interaction of the star rating effect and analyst rating effect appears to subsume the independent effects suggesting investors jointly process the separate ratings when making investment decisions. 


\section{Analyst Ratings and Out-of-Sample Performance}

In this section we examine the relationship between analyst rating initiations and out-of-sample performance. The positive flow response to Gold and Silver rated funds shown in Table 2 and Table 3 may be justified if these ratings are able to identify funds that will outperform their peers in the period following the release of the initial rating. Section 4.1 provides details of our performance measures, and Section 4.2 presents our empirical results.

\subsection{Measuring Out-of-Sample Performance}

Our out-of-sample performance tests use returns measured over the 1, 3, and 6 months following each funds initial rating. Similar to fund flows, we group Negative and Neutral rated funds into a Not Recommended category in our empirical tests. If Morningstar's analysts are able to predict out-of-sample performance, Gold, Silver, and Bronze rated funds should have higher average returns than Not Recommended funds. To test this we regress fund cumulative returns on Gold, Silver, and Bronze indicator variables according to the following specification:

$$
\operatorname{RET}_{i,(1, t+k)}=\alpha+\beta_{\text {Gold }} * \text { Gold }_{i, t}+\beta_{\text {Silver }} * \text { Silver }_{i, t}+\beta_{\text {Bronze }} * \text { Bronze }_{i, t}+\text { Control }_{i, t}+\varepsilon_{i, t}
$$

where $R E T_{i,(1, t+k)}$ represents the fund's cumulative return measured over 1, 3, or 6 months after the month of the analyst rating initiation and $\alpha$ represents the cumulative return for Not Recommended funds net of fixed effects. Gold is an indicator variable that takes the value of 1 if the fund is rated Gold, or 0 otherwise. Thus, the coefficient $\beta_{\text {Gold }}$ gives the incremental cumulative return for Gold rated funds relative to Not Recommended funds. Similarly, Silver and Bronze are corresponding indicators for Silver and Bronze rated funds.

Realized returns do not take risk into consideration. Hence, we also repeat our tests using cumulative risk-adjusted returns as the dependent variable. Risk-adjustment is performed using the Fama and French (1993) three factor model augmented with a momentum factor (Carhart, 1997). The factor loadings used in risk-adjustment are estimated each month using rolling regressions 
where each fund's excess returns over the prior 36 months are regressed on the four factors according to the following specification:

$$
R E T_{i}-r_{f}=\alpha_{i}+\beta_{m} * R M R F+\beta_{h} * H M L+\beta_{s} * S M B+\beta_{u} * U M D+e_{i}
$$

where $r_{f}$ is the risk free rate, $R M R F$ is the excess market return, $H M L$ is the return to the value strategy, $S M B$ is the return to the size strategy, and $U M D$ is the return to the momentum strategy. Similar to our fund flow analysis, we include time, style, and star group fixed effects as well as a rich set of fund characteristics order to address the previously discussed issues. We also repeat our analyses using match-adjusted returns and match-adjusted risk-adjusted returns.

\subsection{Analyst Ratings and Out-of-Sample Performance}

We now present our out-of-sample performance results for analyst rating initiations that occur between September 2011 and December 2012. If Morningstar's analysts identify funds that are expected to outperform their peers, funds with Recommended (Gold, Silver, and Bronze) ratings should have higher average returns than funds with Not Recommended (Neutral and Negative) ratings.

Table 6, Panel A shows the results from regressions of cumulative realized and risk-adjusted returns on Gold, Silver and Bronze indicator variables after controlling for month, style, and star group fixed effects. In Panel B, we additionally use lagged fund characteristics as control variables. None of the risk-adjusted returns are significant and most are negative in magnitude suggesting that even the positively rated funds do not beat passive benchmarks used in Carhart (1997). Gold, Silver, and Bronze funds do not have significantly higher returns than Not Recommended funds at any horizon using both raw and risk-adjusted returns. Surprisingly, at the three month horizon, raw returns of Gold funds are 152 bps lower than returns to Not Recommended funds when raw returns are used, and 8 bps lower than Not Recommended funds when risk-adjusted returns are used (see Panel A). The under performance is 132 bps for raw returns and 8 bps for risk adjusted returns when we add control variables into the regressions as shown in Panel B. However, the difference 
becomes insignificant at the six month horizon. Interestingly, Not Recommended funds (after fixed effects) have positive and significant raw returns in the one, three, and six month window after the rating initiation, but these results disappear after controlling for risk.

Table 7, Panel A shows that Gold rated funds outperform their peers by a higher level than Not Recommended funds outperform their peers over one, three, and six month horizons. The coefficients range between $29 \mathrm{bps}$ at the one month horizon and $186 \mathrm{bps}$ at the six month horizon. However, only the difference in the six month horizon is significant at the $10 \%$ level for realized returns and is not significant at any horizon for risk-adjusted returns. Silver and Bronze rated funds do not significantly outperform Not Recommended funds at any horizon using realized returns or risk-adjusted returns. Results from Wald tests show that, with one exception, Bronze and Not Recommended funds do not significantly underperform Gold rated funds after controlling for month, style, and changes in star ratings. Gold rated funds outperform Bronze rated funds at the $10 \%$ level at the 6 month horizon, however, the significance disappears after risk-adjustment.

Table 7, Panel B shows that after controlling for a wide range of fund characteristics Gold (and Silver) rated funds do not have significantly higher returns than Not Recommended funds at any horizon using both realized and risk-adjusted returns.

The results in Table 7 suggest that Gold rated funds have higher returns than funds rated as Not Recommended after match-adjustment, but the results are mostly weak. After inclusion of additional fund characteristics as control any significance in the differences disappears. Moreover, while returns to Silver and Bronze rated funds were generally lower than Gold rated funds, the difference was not significant at any horizon. We are cautious to interpret these results as the inability of analysts to identify high-quality funds because Morningstar argues that the ratings are designed to predict long-term performance. However, previous research has shown that performance persistence is at best a short term phenomena (Bolen and Busse (2005), Carhart (1997)) and our overall result do not show a strong predictability of the analyst ratings in the post rating period up to six months.

We extend our analysis to examine whether investors could earn a significantly higher return 
by investing in Gold rated funds each month. To do this, we start by forming calendar time portfolios for each of the rating categories. For the Gold rated funds, we compute portfolio returns each month based on an equal-weighted investment in each fund that was rated Gold prior to the beginning of the current month. We repeat the process for each rating category. The four time series of portfolio returns (Gold, Silver, Bronze, and Not Recommended) are used to analyze the performance an investor could expect if he invested his money equally between the funds in a given rating category.

Table 8, Panel A reports the mean returns for each of the ratings-based portfolios as well as the market model alpha (MM Alpha), Fama and French (1993) 3-factor alpha (FF3 Alpha), and the FF3 model augmented with a momentum factor (FF4 Alpha). While mean returns to Gold, Silver, and Bronze portfolios are significant at the $10 \%$ level, none of them are positive after controlling for risk exposure. The results in Table 6, Panel A are consistent with the Gold and Silver rated funds' lack of superior out-of-sample performance identified in Table 5.

Similar to Table 7, we repeat the analysis in Panel A replacing portfolio returns with matchadjusted portfolio returns. Table 8, Panel B shows that match-adjusted returns to the portfolio of Gold rated funds are generally higher (not significant) than returns to Silver and Bronze funds with a few exceptions. The difference between the Gold and Silver portfolios is negative and significant when returns are regressed on the FF4 model.

Together the results in Table 8 fail to demonstrate that an investor could earn significantly higher returns by investing in Gold or Silver rated funds rather than Bronze or Not Recommended Funds.

\section{Conclusion}

Morningstar's introduction of the forward-looking analyst rating provides a novel environment to examine how investors respond to new information from reputable sources. While the backwardlooking star rating, first published in the 1980's, is widely followed, it is not clear if its credibility 
would transfer to the new analyst rating system. We find that investors respond positively to Gold and Silver rated funds relative to other rated funds. Our results hold using realized and residual flows and are robust to the inclusion of a wide range of fund characteristics. These finding are consistent with at least a subset of investors incorporating this new rating system in their investment decisions.

We also examine whether these new analyst ratings predict out-of-sample performance and find little evidence that the new rating system identifies funds that outperform peer funds at horizons of up to 6 months. Morningstar's documentation suggests that the analyst ratings are designed to identify funds that outperform their peers over a full business cycle of at least five years. Given that the analyst rating system has not yet experienced a full cycle, we cannot arrive at a strong conclusion regarding the out-of-sample performance.

Overall, it appears that analyst rating initiations influence investor allocation decisions, but it remains unclear whether the new ratings provide valuable information regarding long-term, outof-sample performance. 


\section{References}

Barber, Brad, Reuven Lehavy, Maureen McNichols, and Brett Trueman, 2001, Can investors profit from the prophets? Security analyst recommendations and stock returns, Journal of Finance 56, 531-563.

Barber, Brad and Douglas Loeffler, 1993, The "Dartboard" column: Second-hand information and price pressure, Journal of Financial and Quantitative Analysis 28, 273-284.

Bergstresser, Daniel, and James Poterba, 2002, Do after-tax returns affect mutual fund inflows?, Journal of Financial Economics 63, 381-414.

Bjerring, James H., Josef Lakonishok, and Theo Vermaelen, 1983, Stock prices and financial analysts' recommendations, Journal of Finance 38, 187-204.

Blake, Christopher R., and Matthew R. Morey, 2000, Morningstar Ratings and Mutual Fund Performance, Journal of Financial and Quantitative Analysis 35, 451-483.

Blume, Marshall E., 1998, An Anatomy of Morningstar Ratings, Financial Analysts Journal 54, 19-27.

Bollen, Nicolas P. B., and Jeffrey A. Busse, 2005, Short-term persistence in mutual fund performance, Review of Financial Studies 18, 569-597

Brown, Nerissa C., Kelsey D. Wie, and Russ Wermers, 2012, Analyst recommendations, mutual fund herding, and overreaction in stock prices, Working Paper.

Carhart, Mark M., 1997, On the Persistence of Mutual Fund Performance, Journal of Finance 52, 57-82.

Chevalier, Judith and Glenn Ellison, 1997, Risk taking by mutual funds as a response to incentives, Journal of Political Economy 105, 1167-1200.

Copeland, Thomas E., and David Mayers, 1982, The Value Line enigma (1965-1978): A case study of performance evaluation issues, Journal of Financial Economics 10, 289-321.

Coval, Joshua and Erik Stafford, 2007, Asset fire sales (and purchases) in equity markets, Journal of Financial Economics 86, 479-512.

Cremers, K. J. Martjin, and Antti Petajisto, 2009, How active is your manager A new measure that predict performance, Review of Financial Studies 22, 3329-3365

Del Guercio, Diane, and Paula A. Tkac, 2002, The determinants of the flow of funds of managed portfolios, Journal of Financial and Quantitative Analysis 37, 523-557.

Del Guercio, Diane, and Paula A. Tkac, 2008, Star power: The effect of Morningstar ratings on mutual fund flow, Journal of Financial and Quantitative Analysis 43, 907-936.

Desai, Hemang and Prem C. Jain, 1995, An analysis of the recommendations of the "Superstar" money managers at Barron's Annual Roundtable, Journal of Finance 50, 1257-1273.

Diether, Karl B., Christopher J. Malloy, and Anna Scherbina, 2002, Differences of opinion and the crosssection of stock returns, Journal of Finance 57, 2113-2141.

Evans, Richard B., 2010, Mutual Fund Incubation, Journal of Finance 65, 1581-1611.

Fama, Eugene F. and Kenneth R. French, 1993, Common risk factors in the returns on stocks and bonds, Journal of Financial Economics 33, 3-56. 
Fama, Eugene F. and James D. MacBeth, 1973, Risk, return, and equilibrium: Empirical tests, Journal of Political Economy 81, 607-636.

Gottesman, Aron, and Matthew R. Morey, 2006, Morningstar mutual fund ratings redux, Working Paper, Pace University.

Kacperczyk, Marcin, and Amit Seru, 2007, Fund manager use of public information New evidence on managerial skills, Journal of Finance 62, 485-528.

Kraussl, Roman, and Ralph Sandelowsky, 2007, The predictive performance of Morningstars mutual fund ratings, Working Paper, University of Amsterdam.

Morey, Matthew R., 2002, Mutual fund age and Morningstar ratings, Financial Analyst Journal 58, 56-63.

Morey, Matthew R., 2005, The kiss of death? A 5-star Morningstar rating, Journal of Investment Management 3, 41-52.

Morningstar, November 15, 2011, Morningstar Introduces Forward-Looking Morningstar Analyst Rating for Funds and Global Fund Reports, Press Release.

Morningstar Fund Research Group, November 15, 2011, Morningstar Analyst Rating for Funds Methodology Document.

Petersen, Mitchell A., 2009, Estimating Standard Errors in Finance Panel Data Sets: Comparing Approaches, Review of Financial Studies 22, 435-480.

Sirri, Erik R., and Peter Tufano, 1998, Costly search and mutual fund flows,Journal of Finance 53, 15891622.

Wermers, 2004 , Is money really "smart"? New evidence on the relation between mutual fund flows, manager behavior, and performance persistence, Working Paper, University of Maryland.

Womack, Kent L, 1996, Do analysts' recommendations have investment value?, Journal of Finance 51, 137-167. 

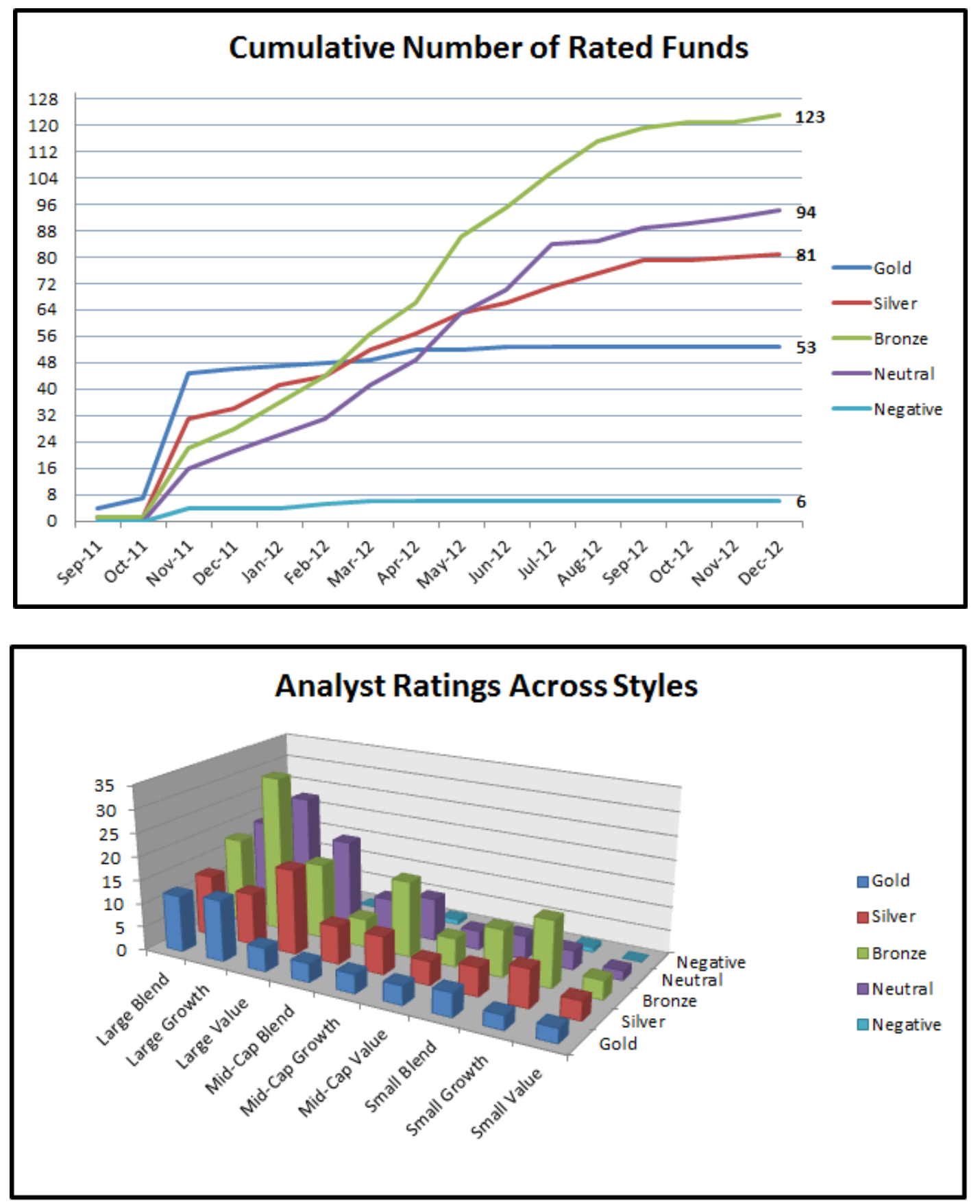

Figure 1. Analyst Ratings Initiations

This figure provides summary statistics regarding the distribution of analyst rating initiations over the period September 2011 to December 2012. Figure 1A (top) shows the distribution of ratings initiations across time. Figure 1B (bottom) shows the distribution of analyst ratings within each style category. 

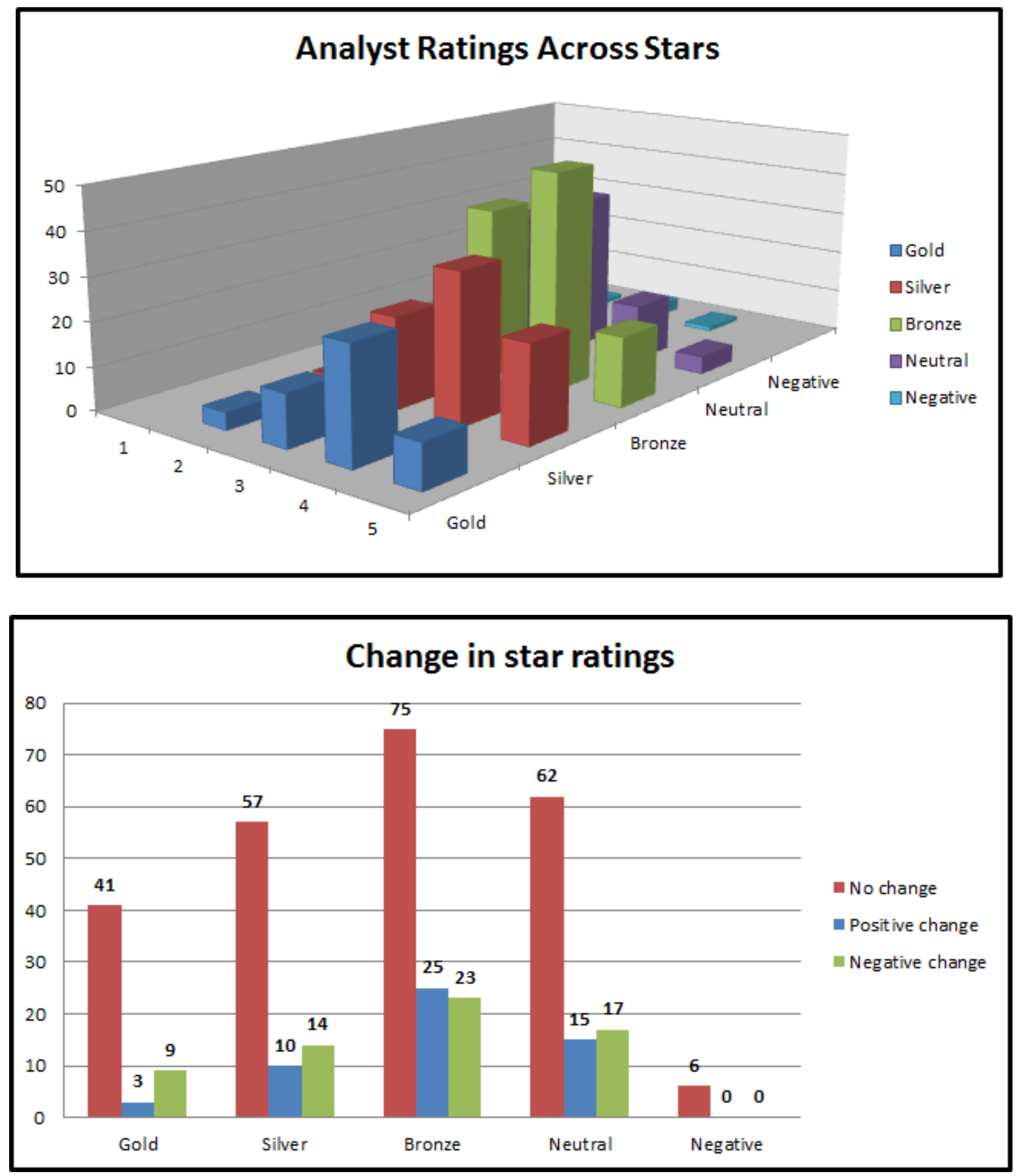

Figure 2. Analyst Ratings Initiations and Star Ratings

This figure shows the distribution of analyst ratings initiations with respect to Morningstar star ratings. Figure 2A (top) shows the distribution of star ratings within each analyst rating category. Figure 2B (bottom) shows the distribution of star ratings changes over the 6-months immediately preceding the analyst rating initiation. 

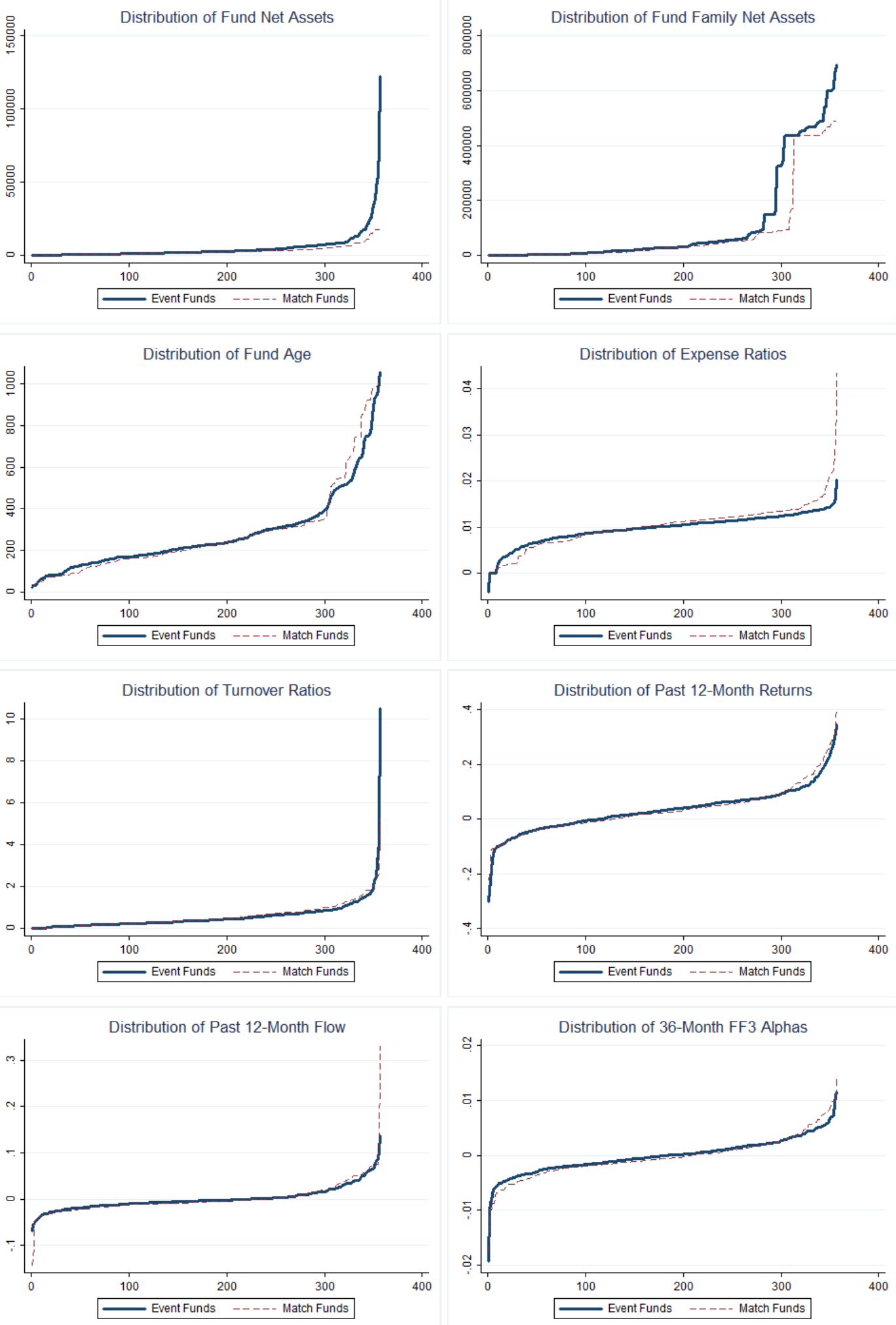

Figure 3. Distribution of Fund Characteristics, Event Funds versus Matched Funds

This figure compares the distribution of characteristics of the event funds with the distribution of characteristics of the best matched funds. The matched funds are identified using a multinomial logistic regression detailed in Section 1.1. Fund characteristics (identified in the header of each panel) include Fund Net Assets, Fund Family Net Assets, Age, Expense Ratio, Turnover Ratio, Fund Load, Past 12-month Returns, Past 12-month Flow, and Past 36-month Fama and French 3-factor alpha. 


\section{Table 1: Fund Characteristics and Analyst Rating Initiations}

Shown below are summary statistics of fund characteristics at the time of analyst rating initiation (September 2011 to December 2012). Panel A presents average values for rated and and unrated funds for the following fund characteristics: Fund net assets (TNA), fund family net assets (Family TNA), age (measured in months), expense ratio, turnover, load, cumulative 12 month return, cumulative 12 month flow, and Fama and French 3-factor alpha. Panel B presents the average values of the same characteristics measured within each analyst rating category.

\begin{tabular}{|c|c|c|c|c|c|c|c|c|c|}
\hline \multicolumn{10}{|c|}{ Panel A: Fund Characteristics, Rated and Unrated } \\
\hline & TNA & Family TNA & Age & Exp. Ratio & Turnover & Load & 12M Return & 12M Flow & FF3 Alpha \\
\hline Unrated & 668.8 & 33,644 & 175.2 & $1.17 \%$ & $83.87 \%$ & $1.28 \%$ & $5.28 \%$ & $-0.13 \%$ & $-0.12 \%$ \\
\hline Rated & 6811.9 & 141,602 & 279.0 & $0.95 \%$ & $47.81 \%$ & $1.32 \%$ & $5.75 \%$ & $-0.17 \%$ & $-0.05 \%$ \\
\hline Difference & 6143.0 & 107,959 & 103.8 & $-0.22 \%$ & $-36.07 \%$ & $0.04 \%$ & $-0.46 \%$ & $-0.04 \%$ & $0.07 \%$ \\
\hline$t$-statistic & 17.0 & 9.6 & 18.4 & -9.4 & -12.4 & 0.8 & -0.2 & -0.5 & 3.4 \\
\hline \multicolumn{10}{|c|}{ Panel B: Fund Characteristics, Analyst Rating Category } \\
\hline & TNA & Family TNA & Age & Exp. Ratio & Turnover & Load & 12M Return & 12M Flow & FF3 Alpha \\
\hline Gold & 9153.6 & 147857.5 & 279.3 & $0.82 \%$ & $29.94 \%$ & $0.86 \%$ & $6.01 \%$ & $0.09 \%$ & $0.02 \%$ \\
\hline Silver & 10162.5 & 133697.6 & 287.0 & $1.00 \%$ & $39.15 \%$ & $1.33 \%$ & $5.76 \%$ & $0.26 \%$ & $0.01 \%$ \\
\hline Bronze & 3352.2 & 61788.4 & 275.5 & $1.11 \%$ & $49.56 \%$ & $1.59 \%$ & $5.69 \%$ & $-0.14 \%$ & $-0.03 \%$ \\
\hline Neutral & 4763.1 & 200377.2 & 312.0 & $0.93 \%$ & $75.22 \%$ & $1.34 \%$ & $5.27 \%$ & $-1.13 \%$ & $-0.23 \%$ \\
\hline Negative & 1177.8 & 98346.6 & 292.2 & $1.21 \%$ & $103.74 \%$ & $1.18 \%$ & $5.86 \%$ & $-2.04 \%$ & $-0.25 \%$ \\
\hline
\end{tabular}




\section{Table 2: Fund Flows and Analyst Ratings Initiations}

Shown below are results from event-time regressions estimated using analyst ratings initiations that occurred over the period September 2011 to December 2012. The dependent variables are event time changes in cumulative flows to analyst rated funds. Flow measures are constructed using monthly realized flows and residual flows; details on the construction of these variables are provided in Section 1.3. The dependent variables are measured over the indicated windows. For example, the $(0,6]-[-6,0)$ window indicates that flows are computed by cumulating flows over the 6 months following the rating initiation and the 6 months immediately preceding the rating initiation, and then taking the difference. Panel A presents results obtained by regressing fund flows on Gold, Silver, and Bronze indicator variables and a constant. Panel B repeats the analysis in Panel A including additional lagged fund characteristics as control variables. $p$-values from a Wald test of the difference between the indicated coefficient estimates are included at the bottom of each of the panels. Month, Style, and Star Group fixed effects are included in each regression. Star Group indicator variables are constructed by combining each fund's event month star rating and its star rating 6 months prior. T-statistics are based on robust standard errors.

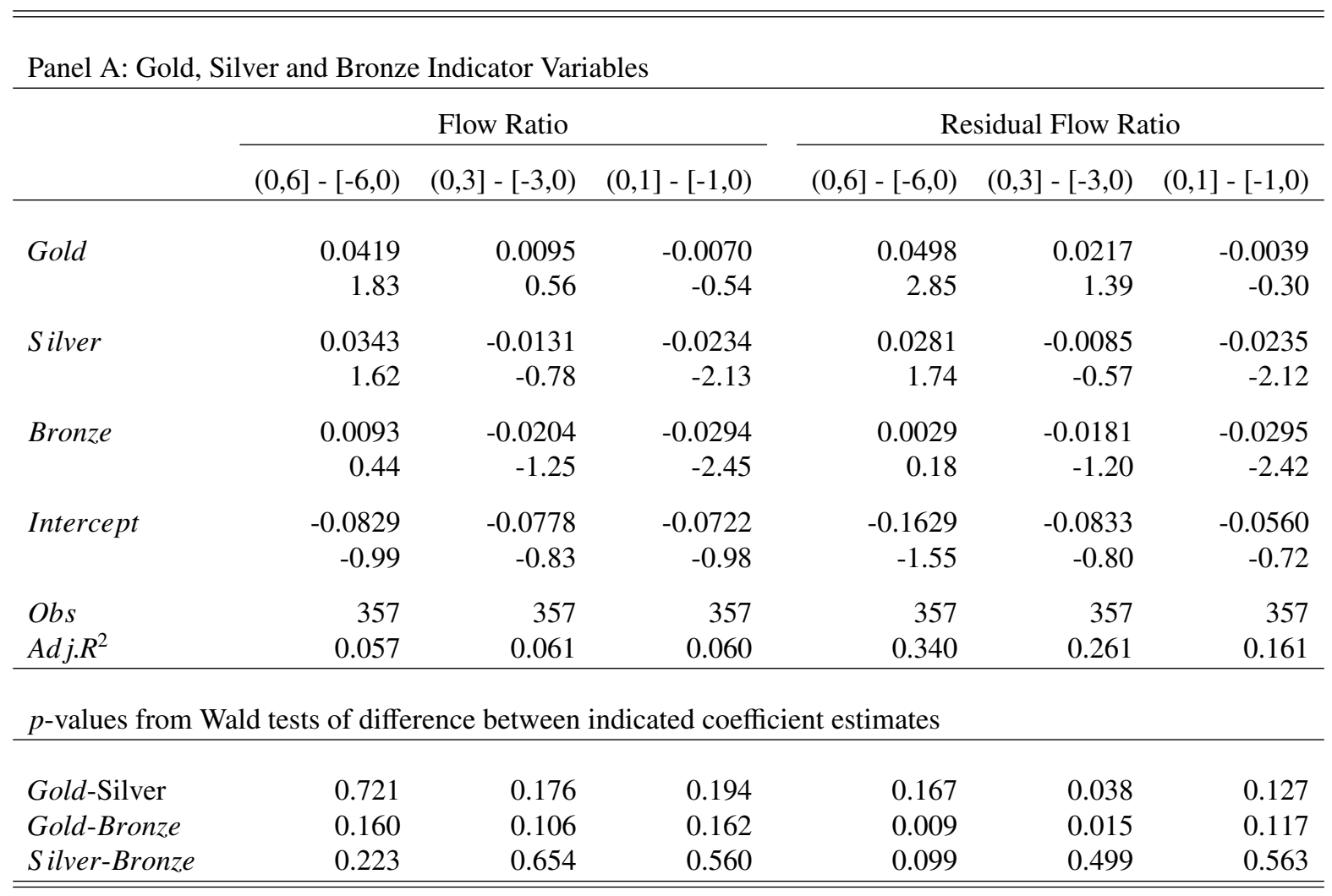


Table 2: Fund Flows and Analyst Ratings Initiations, Cont.

Panel B: Gold, Silver and Bronze Indicator Variables + Lagged Fund Characteristics

\begin{tabular}{|c|c|c|c|c|c|c|}
\hline & \multicolumn{3}{|c|}{ Flow Ratio } & \multicolumn{3}{|c|}{ Residual Flow Ratio } \\
\hline & $(0,6]-[-6,0)$ & $(0,3]-[-3,0)$ & $(0,1]-[-1,0)$ & $(0,6]-[-6,0)$ & $(0,3]-[-3,0)$ & $(0,1]-[-1,0)$ \\
\hline Gold & $\begin{array}{r}0.0542 \\
2.36\end{array}$ & $\begin{array}{r}0.0179 \\
1.03\end{array}$ & $\begin{array}{r}-0.0089 \\
-0.65\end{array}$ & $\begin{array}{r}0.0543 \\
3.13\end{array}$ & $\begin{array}{r}0.0234 \\
1.49\end{array}$ & $\begin{array}{r}-0.0079 \\
-0.56\end{array}$ \\
\hline Silver & $\begin{array}{r}0.0520 \\
2.60\end{array}$ & $\begin{array}{r}0.0052 \\
0.32\end{array}$ & $\begin{array}{r}-0.0116 \\
-1.04\end{array}$ & $\begin{array}{r}0.0375 \\
2.49\end{array}$ & $\begin{array}{r}0.0038 \\
0.27\end{array}$ & $\begin{array}{r}-0.0125 \\
-1.10\end{array}$ \\
\hline Bronze & $\begin{array}{r}0.0297 \\
1.39\end{array}$ & $\begin{array}{r}-0.0010 \\
-0.07\end{array}$ & $\begin{array}{r}-0.0148 \\
-1.30\end{array}$ & $\begin{array}{r}0.0142 \\
0.88\end{array}$ & $\begin{array}{r}-0.0037 \\
-0.26\end{array}$ & $\begin{array}{r}-0.0151 \\
-1.30\end{array}$ \\
\hline $\ln ($ Net Assets $)$ & $\begin{array}{r}-0.0380 \\
-3.11\end{array}$ & $\begin{array}{r}-0.0270 \\
-2.43\end{array}$ & $\begin{array}{r}-0.0207 \\
-2.06\end{array}$ & $\begin{array}{r}-0.0221 \\
-2.40\end{array}$ & $\begin{array}{r}-0.0191 \\
-1.99\end{array}$ & $\begin{array}{r}-0.0194 \\
-1.91\end{array}$ \\
\hline $\ln ($ Family Net Assets $)$ & $\begin{array}{r}0.0064 \\
0.88\end{array}$ & $\begin{array}{r}0.0042 \\
0.63\end{array}$ & $\begin{array}{r}-0.0007 \\
-0.11\end{array}$ & $\begin{array}{r}0.0025 \\
0.47\end{array}$ & $\begin{array}{r}0.0014 \\
0.24\end{array}$ & $\begin{array}{r}-0.0018 \\
-0.29\end{array}$ \\
\hline $\ln (A g e)$ & $\begin{array}{r}0.0066 \\
0.46\end{array}$ & $\begin{array}{r}0.0137 \\
1.13\end{array}$ & $\begin{array}{r}0.0093 \\
1.26\end{array}$ & $\begin{array}{r}0.0038 \\
0.29\end{array}$ & $\begin{array}{r}0.0094 \\
0.77\end{array}$ & $\begin{array}{r}0.0085 \\
1.10\end{array}$ \\
\hline Expense Ratio & $\begin{array}{r}-15.2599 \\
-1.54\end{array}$ & $\begin{array}{r}-14.4879 \\
-1.48\end{array}$ & $\begin{array}{r}-14.1988 \\
-1.44\end{array}$ & $\begin{array}{r}-9.6673 \\
-1.49\end{array}$ & $\begin{array}{r}-12.0325 \\
-1.51\end{array}$ & $\begin{array}{r}-14.3902 \\
-1.46\end{array}$ \\
\hline Turnover & $\begin{array}{r}0.0172 \\
1.42\end{array}$ & $\begin{array}{r}0.0134 \\
1.28\end{array}$ & $\begin{array}{r}-0.0008 \\
-0.17\end{array}$ & $\begin{array}{r}0.0052 \\
0.93\end{array}$ & $\begin{array}{r}0.0057 \\
0.82\end{array}$ & $\begin{array}{r}-0.0007 \\
-0.15\end{array}$ \\
\hline Return(Past12mo.) & $\begin{array}{r}0.2414 \\
1.26\end{array}$ & $\begin{array}{r}-0.1241 \\
-0.72\end{array}$ & $\begin{array}{r}-0.1107 \\
-0.81\end{array}$ & $\begin{array}{r}0.1196 \\
0.70\end{array}$ & $\begin{array}{r}-0.0917 \\
-0.56\end{array}$ & $\begin{array}{r}-0.1106 \\
-0.80\end{array}$ \\
\hline ReturnVol.(Past12mo.) & $\begin{array}{r}1.1245 \\
1.02\end{array}$ & $\begin{array}{r}1.5107 \\
1.62\end{array}$ & $\begin{array}{r}1.5876 \\
2.09\end{array}$ & $\begin{array}{r}0.8685 \\
0.90\end{array}$ & $\begin{array}{r}1.0868 \\
1.22\end{array}$ & $\begin{array}{r}1.4114 \\
1.82\end{array}$ \\
\hline Intercept & $\begin{array}{r}0.0864 \\
0.47\end{array}$ & $\begin{array}{r}0.0384 \\
0.21\end{array}$ & $\begin{array}{r}0.0678 \\
0.41\end{array}$ & $\begin{array}{r}-0.0509 \\
-0.32\end{array}$ & $\begin{array}{r}0.0292 \\
0.17\end{array}$ & $\begin{array}{r}0.0992 \\
0.59\end{array}$ \\
\hline $\begin{array}{l}O b s \\
\text { Adj.R }\end{array}$ & $\begin{array}{r}357 \\
0.161 \\
\end{array}$ & $\begin{array}{r}357 \\
0.164 \\
\end{array}$ & $\begin{array}{r}357 \\
0.191 \\
\end{array}$ & $\begin{array}{r}357 \\
0.380 \\
\end{array}$ & $\begin{array}{r}357 \\
0.317 \\
\end{array}$ & $\begin{array}{r}357 \\
0.272 \\
\end{array}$ \\
\hline$p$-values from Wald tests & fference be & en indicatec & befficient est & & & \\
\hline $\begin{array}{l}\text { Gold-Silver } \\
\text { Gold-Bronze } \\
\text { Silver-Bronze }\end{array}$ & $\begin{array}{l}0.922 \\
0.240 \\
0.260\end{array}$ & $\begin{array}{l}0.472 \\
0.256 \\
0.686\end{array}$ & $\begin{array}{l}0.844 \\
0.667 \\
0.750\end{array}$ & $\begin{array}{l}0.331 \\
0.021 \\
0.129\end{array}$ & $\begin{array}{l}0.217 \\
0.079 \\
0.591\end{array}$ & $\begin{array}{l}0.742 \\
0.609 \\
0.799\end{array}$ \\
\hline
\end{tabular}




\section{Table 3: Match-Adjusted Fund Flows and Analyst Ratings Initiations}

Shown below are results from event-time regressions estimated using analyst ratings initiations that occurred over the period September 2011 to December 2012. The dependent variables are event time changes in cumulative flows to analyst rated funds. Flow measures are constructed using monthly realized flows and residual flows; details on the construction of these variables are provided in Section 1.3. The dependent variables are measured over the indicated windows. For example, the $(0,6]-[-6,0)$ window indicates that flows are computed by cumulating flows over the 6 months following the rating initiation and the 6 months immediately preceding the rating initiation, and then taking the difference. Panel A presents results obtained by regressing match-adjusted fund flows on Gold, Silver, and Bronze indicator variables and a constant. Panel B repeats the analysis in Panel A including additional lagged fund characteristics as control variables. $p$-values from a Wald test of the difference between the indicated coefficient estimates are included at the bottom of each of the panels. Match-adjustment is detailed in Section 2.2. Month, Style, and Star Group fixed effects are included in each regression. Star Group indicator variables are constructed by combining each fund's event month star rating and its star rating 6 months prior. T-statistics are based on robust standard errors.

Panel A: Gold, Silver and Bronze Indicator Variables

\begin{tabular}{|c|c|c|c|c|c|c|}
\hline & \multicolumn{3}{|c|}{ Flow Ratio } & \multicolumn{3}{|c|}{ Residual Flow Ratio } \\
\hline & $(0,6]-[-6,0)$ & $(0,3]-[-3,0)$ & $(0,1]-[-1,0)$ & $(0,6]-[-6,0)$ & $(0,3]-[-3,0)$ & $(0,1]-[-1,0)$ \\
\hline Gold & $\begin{array}{r}0.1153 \\
2.56\end{array}$ & $\begin{array}{r}0.0280 \\
1.13\end{array}$ & $\begin{array}{r}-0.0138 \\
-0.87\end{array}$ & $\begin{array}{r}0.1041 \\
3.06\end{array}$ & $\begin{array}{r}0.0287 \\
1.24\end{array}$ & $\begin{array}{r}-0.0139 \\
-0.87\end{array}$ \\
\hline Silver & $\begin{array}{r}0.0727 \\
1.95\end{array}$ & $\begin{array}{r}0.0011 \\
0.05\end{array}$ & $\begin{array}{r}-0.0316 \\
-2.41\end{array}$ & $\begin{array}{r}0.0579 \\
2.08\end{array}$ & $\begin{array}{r}-0.0012 \\
-0.06\end{array}$ & $\begin{array}{r}-0.0338 \\
-2.59\end{array}$ \\
\hline Bronze & $\begin{array}{r}0.0269 \\
0.79\end{array}$ & $\begin{array}{r}-0.0101 \\
-0.44\end{array}$ & $\begin{array}{r}-0.0329 \\
-2.51\end{array}$ & $\begin{array}{r}0.0121 \\
0.44\end{array}$ & $\begin{array}{r}-0.0155 \\
-0.74\end{array}$ & $\begin{array}{r}-0.0350 \\
-2.67\end{array}$ \\
\hline Intercept & $\begin{array}{r}-0.1243 \\
-0.84\end{array}$ & $\begin{array}{r}-0.0661 \\
-0.64\end{array}$ & $\begin{array}{r}-0.0394 \\
-0.54\end{array}$ & $\begin{array}{r}-0.2121 \\
-1.29\end{array}$ & $\begin{array}{r}-0.1238 \\
-1.14\end{array}$ & $\begin{array}{r}-0.0620 \\
-0.83\end{array}$ \\
\hline $\begin{array}{l}O b s \\
\text { Adj.R }\end{array}$ & $\begin{array}{r}355 \\
0.079 \\
\end{array}$ & $\begin{array}{r}356 \\
0.050 \\
\end{array}$ & $\begin{array}{r}357 \\
0.088 \\
\end{array}$ & $\begin{array}{r}355 \\
0.148 \\
\end{array}$ & $\begin{array}{r}356 \\
0.068 \\
\end{array}$ & $\begin{array}{r}357 \\
0.098 \\
\end{array}$ \\
\hline$p$-values from $\mathrm{V}$ & tests of diff & nce between & dicated coe & t estimates & & \\
\hline $\begin{array}{l}\text { Gold-Silver } \\
\text { Gold-Bronze } \\
\text { Silver-Bronze }\end{array}$ & $\begin{array}{l}0.268 \\
0.025 \\
0.148\end{array}$ & $\begin{array}{l}0.200 \\
0.109 \\
0.583\end{array}$ & $\begin{array}{l}0.165 \\
0.229 \\
0.912\end{array}$ & $\begin{array}{l}0.114 \\
0.002 \\
0.060\end{array}$ & $\begin{array}{l}0.115 \\
0.043 \\
0.431\end{array}$ & $\begin{array}{l}0.118 \\
0.184 \\
0.920\end{array}$ \\
\hline
\end{tabular}


Table 3: Match-Adjusted Fund Flows and Analyst Ratings Initiations, Cont.

Panel B: Gold, Silver and Bronze Indicator Variables + Lagged Fund Characteristics

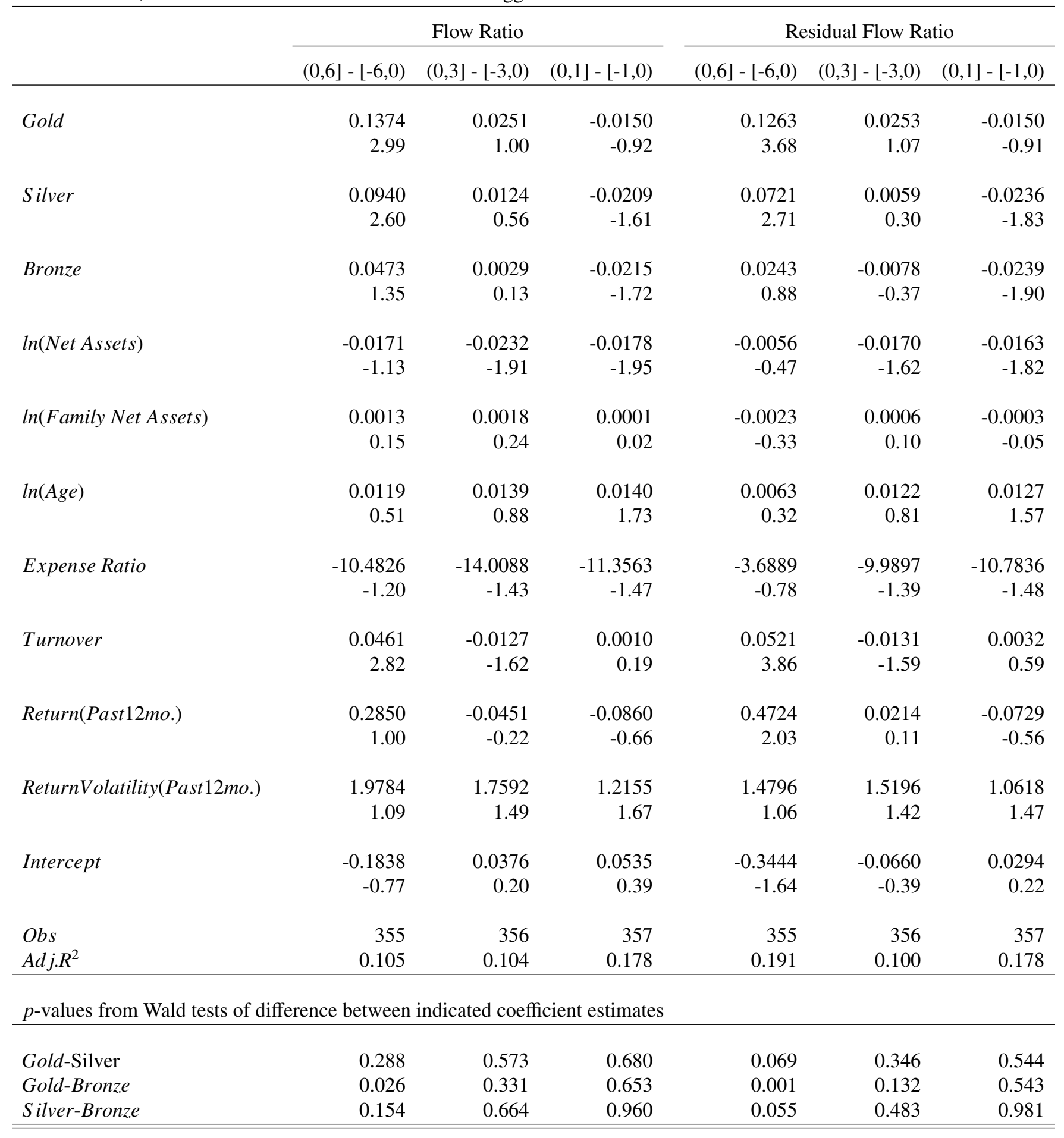




\section{Table 4: Analyst Ratings within High and Low Star Rating Groups}

Shown below are results from event-time regressions estimated within High and Low Star groups using analyst ratings initiations that occurred over the period September 2011 to December 2012. High Star funds are those with star ratings of 4 or 5, while Low Star funds are those with a star rating below 4 . The dependent variables are event time changes in cumulative flows to analyst rated funds. Flow measures are constructed using monthly realized flows and residual flows; details on the construction of these variables are provided in Section 1.3. The dependent variable is computed by cumulating flows over the 6 months following the rating initiation and the 6 months immediately preceding the rating initiation, and then taking the difference. Coefficient estimates are obtained by regressing 6 month change in fund flow on Gold, Silver, and Bronze indicator variables, lagged fund characteristics, and a constant within the High Star and Low Star groups of funds. $p$-values from a Wald test of the difference between the indicated coefficient estimates are included at the bottom of each of the panels. Month, Style, and Star Group fixed effects are included in each regression. Star Group indicator variables are constructed by combining each fund's event month star rating and its star rating 6 months prior. T-statistics are based on robust standard errors.

\begin{tabular}{|c|c|c|c|c|}
\hline \multirow[b]{2}{*}{ Star Rating } & \multicolumn{2}{|l|}{ Flow Ratio } & \multicolumn{2}{|c|}{ Residual Flow Ratio } \\
\hline & High Star & Low Star & High Star & Low Star \\
\hline Gold & $\begin{array}{r}0.0955 \\
2.44\end{array}$ & $\begin{array}{r}0.0425 \\
1.12\end{array}$ & $\begin{array}{r}0.0812 \\
2.77\end{array}$ & $\begin{array}{r}0.0477 \\
1.54\end{array}$ \\
\hline Silver & $\begin{array}{r}0.0894 \\
2.51\end{array}$ & $\begin{array}{r}0.0152 \\
0.49\end{array}$ & $\begin{array}{r}0.0740 \\
2.80\end{array}$ & $\begin{array}{r}0.0079 \\
0.30\end{array}$ \\
\hline Bronze & $\begin{array}{r}0.0894 \\
2.60\end{array}$ & $\begin{array}{r}-0.0029 \\
-0.09\end{array}$ & $\begin{array}{r}0.0617 \\
2.44\end{array}$ & $\begin{array}{r}-0.0144 \\
-0.56\end{array}$ \\
\hline $\ln ($ Net Assets $)$ & $\begin{array}{r}-0.0366 \\
-2.04\end{array}$ & $\begin{array}{r}-0.0413 \\
-2.44\end{array}$ & $\begin{array}{r}-0.0174 \\
-1.28\end{array}$ & $\begin{array}{r}-0.0253 \\
-2.02\end{array}$ \\
\hline $\ln ($ Family Net Assets) & $\begin{array}{r}0.0165 \\
1.51\end{array}$ & $\begin{array}{r}0.0017 \\
0.16\end{array}$ & $\begin{array}{r}0.0070 \\
0.87\end{array}$ & $\begin{array}{r}0.0013 \\
0.16\end{array}$ \\
\hline $\ln (A g e)$ & $\begin{array}{r}-0.0348 \\
-1.65\end{array}$ & $\begin{array}{r}0.0329 \\
1.48\end{array}$ & $\begin{array}{r}-0.0310 \\
-1.75\end{array}$ & $\begin{array}{r}0.0277 \\
1.50\end{array}$ \\
\hline Expense Ratio & $\begin{array}{r}-1.1978 \\
-0.24\end{array}$ & $\begin{array}{r}-21.4887 \\
-1.56\end{array}$ & $\begin{array}{r}-0.1788 \\
-0.04\end{array}$ & $\begin{array}{r}-12.6978 \\
-1.40\end{array}$ \\
\hline Turnover & $\begin{array}{r}0.0209 \\
2.15\end{array}$ & $\begin{array}{r}-0.0043 \\
-0.23\end{array}$ & $\begin{array}{r}0.0039 \\
0.64\end{array}$ & $\begin{array}{r}0.0033 \\
0.23\end{array}$ \\
\hline Return(Past12mo.) & $\begin{array}{r}0.3335 \\
1.09\end{array}$ & $\begin{array}{r}0.3796 \\
1.31\end{array}$ & $\begin{array}{r}0.1298 \\
0.56\end{array}$ & $\begin{array}{r}0.2764 \\
1.03\end{array}$ \\
\hline ReturnVolatility(Past $12 \mathrm{mo})$. & $\begin{array}{r}-1.0447 \\
-0.75\end{array}$ & $\begin{array}{r}3.8097 \\
2.20\end{array}$ & $\begin{array}{r}-1.1358 \\
-1.08\end{array}$ & $\begin{array}{r}3.4212 \\
2.31\end{array}$ \\
\hline Intercept & $\begin{array}{r}0.3458 \\
1.68\end{array}$ & $\begin{array}{r}-0.1478 \\
-0.59\end{array}$ & $\begin{array}{r}0.2691 \\
1.68\end{array}$ & $\begin{array}{r}-0.3034 \\
-1.52\end{array}$ \\
\hline $\begin{array}{l}\text { Obs } \\
\text { Adj. } R^{2}\end{array}$ & $\begin{array}{r}176 \\
0.160\end{array}$ & $\begin{array}{r}181 \\
0.170\end{array}$ & $\begin{array}{r}176 \\
0.390\end{array}$ & $\begin{array}{r}181 \\
0.403\end{array}$ \\
\hline
\end{tabular}




\section{Table 5: High Star Rating within Recommended and Not Recommended Analyst Rating Groups}

Shown below are results from event-time regressions estimated within Recommended and Not Recommended analyst rating groups using analyst ratings initiations that occurred over the period September 2011 to December 2012. Recommended funds are those with analyst ratings of Gold, Silver, or Bronze. Not Recommended funds are those with analyst ratings of Neutral and Negative. High Star funds are those with star ratings of 4 or 5 . The dependent variables are event time changes in cumulative flows to analyst rated funds. Flow measures are constructed using monthly realized flows and residual flows; details on the construction of these variables are provided in Section 1.3. The dependent variable is computed by cumulating flows over the 6 months following the rating initiation and the 6 months immediately preceding the rating initiation, and then taking the difference. Coefficient estimates are obtained by regressing 6 month change in fund flow on a High Star indicator variables, lagged fund characteristics, and a constant within the Recommended and Not Recommended groups of funds. $p$-values from a Wald test of the difference between the indicated coefficient estimates are included at the bottom of each of the panels. Month, Style, and Star Group fixed effects are included in each regression. Star Group indicator variables are constructed by combining each fund's event month star rating and its star rating 6 months prior. T-statistics are based on robust standard errors.

\begin{tabular}{|c|c|c|c|c|}
\hline \multirow[b]{2}{*}{ Analyst Rating } & \multicolumn{2}{|l|}{ Flow Ratio } & \multicolumn{2}{|c|}{ Residual Flow Ratio } \\
\hline & Recommended & Not Recommended & Recommended & Not Recommended \\
\hline \multirow[t]{2}{*}{ HighStar } & 0.2542 & 0.0318 & 0.2958 & -0.0300 \\
\hline & 2.66 & 0.26 & 2.09 & -0.34 \\
\hline \multirow[t]{2}{*}{$\ln ($ Net Assets $)$} & -0.0297 & -0.0430 & -0.0149 & -0.0266 \\
\hline & -2.28 & -1.68 & -1.41 & -1.59 \\
\hline \multirow[t]{2}{*}{$\ln ($ Family Net Assets $)$} & 0.0085 & -0.0205 & 0.0010 & -0.0150 \\
\hline & 1.18 & -1.12 & 0.18 & -1.27 \\
\hline \multirow[t]{2}{*}{$\ln (A g e)$} & 0.0093 & -0.0353 & 0.0097 & -0.0319 \\
\hline & 0.57 & -1.33 & 0.60 & -1.70 \\
\hline \multirow[t]{2}{*}{ Expense Ratio } & -7.7826 & -28.8476 & -6.6162 & -18.3977 \\
\hline & -2.09 & -2.22 & -1.91 & -2.25 \\
\hline \multirow[t]{2}{*}{ Turnover } & 0.0275 & -0.0099 & 0.0134 & -0.0183 \\
\hline & 2.65 & -0.30 & 1.81 & -1.02 \\
\hline \multirow[t]{2}{*}{ Return(Past $12 m o)}$. & 0.2111 & 0.4397 & 0.0024 & 0.4325 \\
\hline & 1.01 & 0.96 & 0.01 & 1.28 \\
\hline \multirow[t]{2}{*}{ ReturnVolatility(Past12mo.) } & 0.2624 & 6.2901 & 0.2025 & 3.7397 \\
\hline & 0.27 & 1.66 & 0.22 & 1.63 \\
\hline \multirow[t]{2}{*}{ Intercept } & -0.0030 & 0.3933 & -0.1055 & 0.1739 \\
\hline & -0.02 & 0.97 & -0.70 & 0.65 \\
\hline Obs & 257 & 100 & 257 & 100 \\
\hline$A d j \cdot R^{2}$ & 0.184 & 0.420 & 0.387 & 0.625 \\
\hline
\end{tabular}




\section{Table 6: Fund Returns and Analyst Ratings Initiations}

Shown below are results from event-time regressions estimated using analyst rating initiations that occurred over the period September 2011 to December 2012. The dependent variables are event time cumulative returns to analyst rated funds. Return measures are constructed using monthly realized returns and riskadjusted returns where risk-adjustment is computed using the Fama and French 3-factor (FF3) model augmented with the Carhart (1997) momentum factor (FF4). The dependent variables are measured over the indicated windows. For example, the $(0,6]$ window indicates that returns are compounded over the 6 months following the rating initiation, excluding the event month. Panel A presents results where the obtained by regressing returns on Gold, Silver, and Bronze indicator variables and a constant. Panel B repeats the analysis in Panel A including additional lagged fund characteristics as control variables. $p$-values from a Wald test of the difference between the indicated coefficient estimates are included at the bottom of each of the panels. Month, Style, and Star Group fixed effects are included in each regression. Star Group indicator variables are constructed by combining each fund's event month star rating and its star rating 6 months prior. T-statistics are based on robust standard errors.

Panel A: Gold, Silver and Bronze Indicator Variables

\begin{tabular}{|c|c|c|c|c|c|c|c|c|}
\hline & \multicolumn{4}{|c|}{ Realized Returns } & \multicolumn{4}{|c|}{ Risk-Adjusted Returns (FF4, 36M) } \\
\hline & Event Month & $(0,1]$ & $(0,3]$ & $(0,6]$ & Event Mo. & $(0,1]$ & $(0,3]$ & $(0,6]$ \\
\hline Gold & $\begin{array}{r}0.0009 \\
0.33\end{array}$ & $\begin{array}{r}0.0012 \\
0.46\end{array}$ & $\begin{array}{r}-0.0152 \\
-3.06\end{array}$ & $\begin{array}{r}-0.0027 \\
-0.43\end{array}$ & $\begin{array}{r}0.0032 \\
1.35\end{array}$ & $\begin{array}{r}0.0000 \\
-0.02\end{array}$ & $\begin{array}{r}-0.0080 \\
-1.95\end{array}$ & $\begin{array}{r}-0.0011 \\
-0.20\end{array}$ \\
\hline Silver & $\begin{array}{r}-0.0064 \\
-2.90\end{array}$ & $\begin{array}{r}0.0015 \\
0.67\end{array}$ & $\begin{array}{r}-0.0045 \\
-1.07\end{array}$ & $\begin{array}{r}0.0009 \\
0.17\end{array}$ & $\begin{array}{r}-0.0019 \\
-0.84\end{array}$ & $\begin{array}{r}-0.0002 \\
-0.08\end{array}$ & $\begin{array}{r}-0.0038 \\
-1.08\end{array}$ & $\begin{array}{r}0.0059 \\
1.22\end{array}$ \\
\hline Bronze & $\begin{array}{r}-0.0017 \\
-1.02\end{array}$ & $\begin{array}{r}0.0024 \\
1.23\end{array}$ & $\begin{array}{r}-0.0060 \\
-1.88\end{array}$ & $\begin{array}{r}-0.0077 \\
-1.80\end{array}$ & $\begin{array}{r}-0.0013 \\
-0.77\end{array}$ & $\begin{array}{r}0.0021 \\
1.18\end{array}$ & $\begin{array}{r}-0.0056 \\
-2.08\end{array}$ & $\begin{array}{r}-0.0042 \\
-1.09\end{array}$ \\
\hline Intercept & $\begin{array}{r}-0.0835 \\
-10.16\end{array}$ & $\begin{array}{r}0.1377 \\
18.11\end{array}$ & $\begin{array}{r}0.1301 \\
8.33\end{array}$ & $\begin{array}{r}0.2550 \\
13.60\end{array}$ & $\begin{array}{r}0.0028 \\
0.36\end{array}$ & $\begin{array}{r}0.0099 \\
1.62\end{array}$ & $\begin{array}{r}-0.0041 \\
-0.40\end{array}$ & $\begin{array}{r}-0.0319 \\
-2.24\end{array}$ \\
\hline $\begin{array}{l}\text { Obs } \\
\text { Adj.R } R^{2}\end{array}$ & $\begin{array}{r}357 \\
0.893\end{array}$ & $\begin{array}{r}357 \\
0.859 \\
\end{array}$ & $\begin{array}{r}357 \\
0.877 \\
\end{array}$ & $\begin{array}{r}357 \\
0.725 \\
\end{array}$ & $\begin{array}{r}357 \\
0.245 \\
\end{array}$ & $\begin{array}{r}357 \\
0.163 \\
\end{array}$ & $\begin{array}{r}357 \\
0.049 \\
\end{array}$ & $\begin{array}{r}352 \\
0.120 \\
\end{array}$ \\
\hline$p$-values from & tests of diffe & ce be & en indi & d coef & estimates & & & \\
\hline $\begin{array}{l}\text { Gold-Silver } \\
\text { Gold-Bronze } \\
\text { Silver-Bronze }\end{array}$ & $\begin{array}{l}0.007 \\
0.293 \\
0.020\end{array}$ & $\begin{array}{l}0.902 \\
0.655 \\
0.698\end{array}$ & $\begin{array}{l}0.024 \\
0.044 \\
0.675\end{array}$ & $\begin{array}{l}0.520 \\
0.403 \\
0.092\end{array}$ & $\begin{array}{l}0.029 \\
0.031 \\
0.764\end{array}$ & $\begin{array}{l}0.955 \\
0.361 \\
0.265\end{array}$ & $\begin{array}{l}0.253 \\
0.525 \\
0.552\end{array}$ & $\begin{array}{l}0.167 \\
0.557 \\
0.024\end{array}$ \\
\hline
\end{tabular}


Table 6: Fund Returns and Analyst Ratings Initiations, Cont.

Panel B: Gold, Silver and Bronze Indicator Variables + Lagged Fund Characteristics

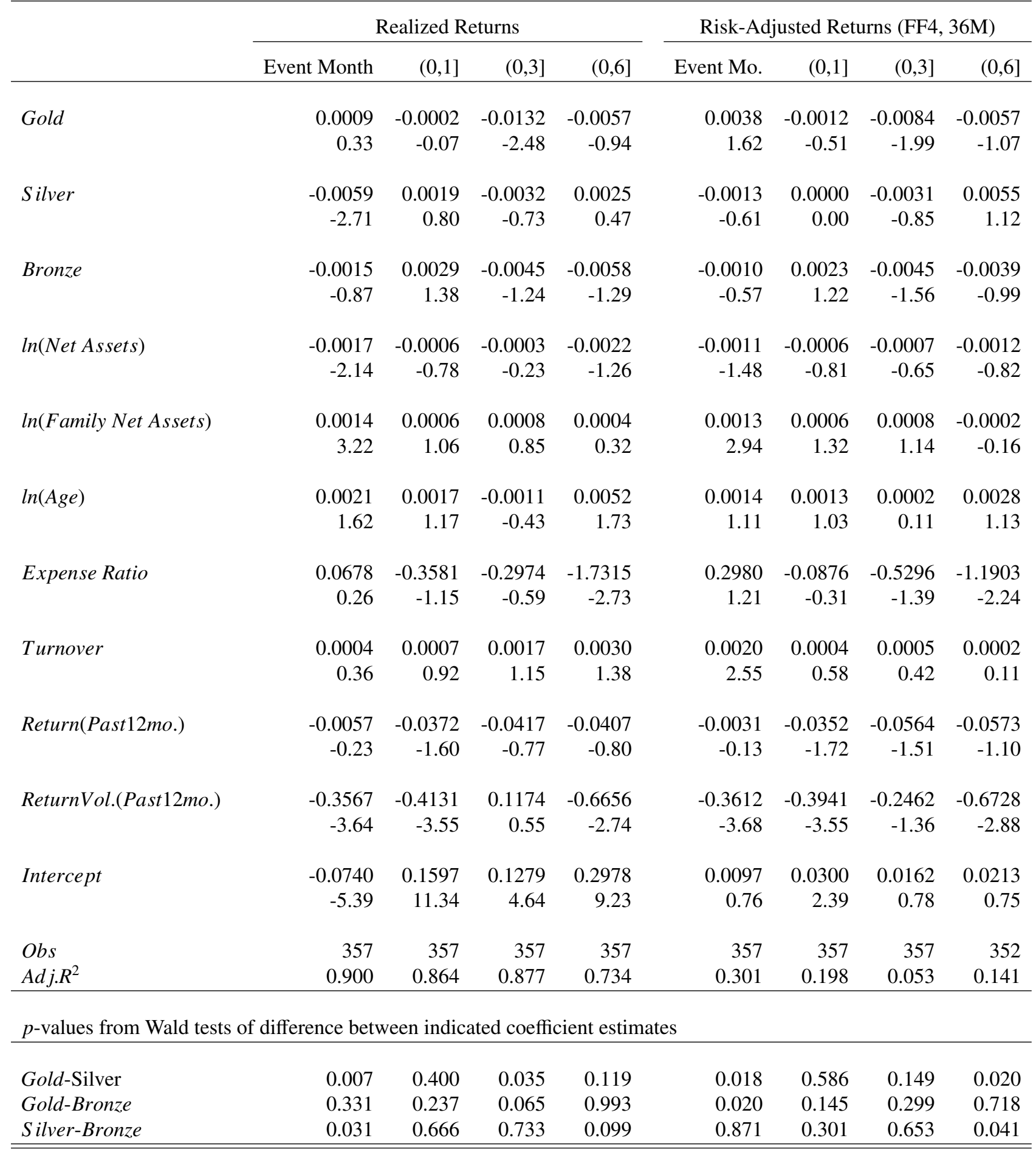




\section{Table 7: Match-Adjusted Fund Returns and Analyst Ratings Initiations}

Shown below are results from event-time regressions estimated using analyst ratings initiations that occurred over the period September 2011 to December 2012. The dependent variables are event time cumulative returns to analyst rated funds. Return measures are constructed using monthly realized returns and riskadjusted returns where risk-adjustment is computed using the Fama and French 3-factor (FF3) model augmented with the Carhart (1997) momentum factor (FF4). The dependent variables are measured over the indicated windows. For example, the $(0,6]$ window indicates that returns are compounded over the 6 months following the rating initiation, excluding the event month. Panel A presents results where the obtained by regressing match-adjusted returns on Gold, Silver, and Bronze indicator variables and a constant. Panel B repeats the analysis in Panel A including additional lagged fund characteristics as control variables. $p$-values from a Wald test of the difference between the indicated coefficient estimates are included at the bottom of each of the panels. Match-adjustment is detailed in Section 2.2. Month, Style, and Star Group fixed effects are included in each regression. Star Group indicator variables are constructed by combining each fund's event month star rating and its star rating 6 months prior. T-statistics are based on robust standard errors.

Panel A: Gold, Silver and Bronze Indicator Variables

\begin{tabular}{|c|c|c|c|c|c|c|c|c|}
\hline & \multicolumn{4}{|c|}{ Realized Returns } & \multicolumn{4}{|c|}{ Risk-Adjusted Returns (FF4, 36M) } \\
\hline & Event Month & $(0,1]$ & $(0,3]$ & $(0,6]$ & Event Mo. & $(0,1]$ & $(0,3]$ & $(0,6]$ \\
\hline Gold & $\begin{array}{r}-0.0043 \\
-1.35\end{array}$ & $\begin{array}{r}0.0029 \\
0.80\end{array}$ & $\begin{array}{r}0.0062 \\
1.16\end{array}$ & $\begin{array}{r}0.0186 \\
1.72\end{array}$ & $\begin{array}{r}-0.0014 \\
-0.51\end{array}$ & $\begin{array}{r}0.0020 \\
0.66\end{array}$ & $\begin{array}{r}0.0032 \\
0.66\end{array}$ & $\begin{array}{r}0.0148 \\
1.47\end{array}$ \\
\hline Silver & $\begin{array}{r}-0.0096 \\
-3.20\end{array}$ & $\begin{array}{r}-0.0001 \\
-0.02\end{array}$ & $\begin{array}{r}0.0053 \\
1.16\end{array}$ & $\begin{array}{r}0.0067 \\
0.99\end{array}$ & $\begin{array}{r}-0.0050 \\
-1.78\end{array}$ & $\begin{array}{r}-0.0002 \\
-0.07\end{array}$ & $\begin{array}{r}0.0027 \\
0.66\end{array}$ & $\begin{array}{r}0.0090 \\
1.28\end{array}$ \\
\hline Bronze & $\begin{array}{r}0.0006 \\
0.26\end{array}$ & $\begin{array}{r}0.0040 \\
1.61\end{array}$ & $\begin{array}{r}0.0013 \\
0.36\end{array}$ & $\begin{array}{r}0.0010 \\
0.19\end{array}$ & $\begin{array}{r}0.0002 \\
0.09\end{array}$ & $\begin{array}{r}0.0030 \\
1.44\end{array}$ & $\begin{array}{r}-0.0001 \\
-0.02\end{array}$ & $\begin{array}{r}0.0001 \\
0.01\end{array}$ \\
\hline Intercept & $\begin{array}{r}0.0202 \\
1.83\end{array}$ & $\begin{array}{r}-0.0185 \\
-1.31\end{array}$ & $\begin{array}{r}-0.0249 \\
-0.89\end{array}$ & $\begin{array}{r}-0.0682 \\
-1.98\end{array}$ & $\begin{array}{r}0.0133 \\
1.32\end{array}$ & $\begin{array}{r}-0.0065 \\
-0.82\end{array}$ & $\begin{array}{r}-0.0211 \\
-0.98\end{array}$ & $\begin{array}{r}-0.0475 \\
-1.80\end{array}$ \\
\hline $\begin{array}{l}O b s \\
A d j . R^{2}\end{array}$ & $\begin{array}{r}357 \\
0.281 \\
\end{array}$ & $\begin{array}{r}357 \\
0.008 \\
\end{array}$ & $\begin{array}{r}356 \\
0.070 \\
\end{array}$ & $\begin{array}{r}356 \\
0.094 \\
\end{array}$ & $\begin{array}{r}357 \\
-0.003 \\
\end{array}$ & $\begin{array}{r}357 \\
0.013 \\
\end{array}$ & $\begin{array}{r}356 \\
0.009 \\
\end{array}$ & $\begin{array}{r}351 \\
0.021 \\
\end{array}$ \\
\hline$p$-values from & ests of diff & e bety & $n$ indi & coeff & estimates & & & \\
\hline $\begin{array}{l}\text { Gold-Silver } \\
\text { Gold-Bronze } \\
\text { Silver-Bronze }\end{array}$ & $\begin{array}{l}0.120 \\
0.121 \\
0.001\end{array}$ & $\begin{array}{l}0.400 \\
0.747 \\
0.152\end{array}$ & $\begin{array}{l}0.881 \\
0.355 \\
0.380\end{array}$ & $\begin{array}{l}0.216 \\
0.080 \\
0.380\end{array}$ & $\begin{array}{l}0.237 \\
0.566 \\
0.060\end{array}$ & $\begin{array}{l}0.427 \\
0.709 \\
0.162\end{array}$ & $\begin{array}{l}0.906 \\
0.480 \\
0.482\end{array}$ & $\begin{array}{l}0.485 \\
0.101 \\
0.136\end{array}$ \\
\hline
\end{tabular}


Table 7: Match-Adjusted Fund Returns and Analyst Ratings Initiations, Cont.

Panel B: Gold, Silver and Bronze Indicator Variables + Lagged Fund Characteristics

\begin{tabular}{|c|c|c|c|c|c|c|c|c|}
\hline & \multicolumn{4}{|c|}{ Realized Returns } & \multicolumn{4}{|c|}{ Risk-Adjusted Returns (FF4, 36M) } \\
\hline & Event Month & $(0,1]$ & $(0,3]$ & $(0,6]$ & Event Mo. & $(0,1]$ & $(0,3]$ & $(0,6]$ \\
\hline Gold & $\begin{array}{r}-0.0080 \\
-2.51\end{array}$ & $\begin{array}{r}0.0005 \\
0.15\end{array}$ & $\begin{array}{r}0.0078 \\
1.41\end{array}$ & $\begin{array}{r}0.0166 \\
1.57\end{array}$ & $\begin{array}{r}-0.0044 \\
-1.51\end{array}$ & $\begin{array}{r}-0.0006 \\
-0.19\end{array}$ & $\begin{array}{r}0.0010 \\
0.21\end{array}$ & $\begin{array}{r}0.0087 \\
0.87\end{array}$ \\
\hline Silver & $\begin{array}{r}-0.0094 \\
-3.20\end{array}$ & $\begin{array}{r}-0.0005 \\
-0.17\end{array}$ & $\begin{array}{r}0.0054 \\
1.19\end{array}$ & $\begin{array}{r}0.0066 \\
0.99\end{array}$ & $\begin{array}{r}-0.0053 \\
-1.88\end{array}$ & $\begin{array}{r}-0.0004 \\
-0.19\end{array}$ & $\begin{array}{r}0.0026 \\
0.66\end{array}$ & $\begin{array}{r}0.0074 \\
1.05\end{array}$ \\
\hline Bronze & $\begin{array}{r}0.0004 \\
0.17\end{array}$ & $\begin{array}{r}0.0046 \\
1.75\end{array}$ & $\begin{array}{r}0.0030 \\
0.71\end{array}$ & $\begin{array}{r}0.0019 \\
0.35\end{array}$ & $\begin{array}{r}-0.0001 \\
-0.06\end{array}$ & $\begin{array}{r}0.0036 \\
1.70\end{array}$ & $\begin{array}{r}0.0018 \\
0.51\end{array}$ & $\begin{array}{r}0.0000 \\
0.00\end{array}$ \\
\hline $\ln ($ Net Assets $)$ & $\begin{array}{r}-0.0030 \\
-2.85\end{array}$ & $\begin{array}{r}-0.0011 \\
-1.03\end{array}$ & $\begin{array}{r}0.0012 \\
0.74\end{array}$ & $\begin{array}{r}-0.0013 \\
-0.52\end{array}$ & $\begin{array}{r}-0.0018 \\
-1.66\end{array}$ & $\begin{array}{r}-0.0019 \\
-1.89\end{array}$ & $\begin{array}{r}-0.0005 \\
-0.34\end{array}$ & $\begin{array}{r}-0.0017 \\
-0.74\end{array}$ \\
\hline $\ln ($ Family Net Assets $)$ & $\begin{array}{r}0.0004 \\
0.68\end{array}$ & $\begin{array}{r}0.0001 \\
0.16\end{array}$ & $\begin{array}{r}0.0012 \\
1.16\end{array}$ & $\begin{array}{r}0.0007 \\
0.44\end{array}$ & $\begin{array}{r}0.0004 \\
0.65\end{array}$ & $\begin{array}{r}0.0001 \\
0.14\end{array}$ & $\begin{array}{r}0.0010 \\
1.19\end{array}$ & $\begin{array}{r}-0.0001 \\
-0.05\end{array}$ \\
\hline $\ln (A g e)$ & $\begin{array}{r}0.0051 \\
3.03\end{array}$ & $\begin{array}{r}-0.0007 \\
-0.33\end{array}$ & $\begin{array}{r}-0.0052 \\
-1.83\end{array}$ & $\begin{array}{r}0.0000 \\
0.00\end{array}$ & $\begin{array}{r}0.0024 \\
1.42\end{array}$ & $\begin{array}{r}-0.0001 \\
-0.07\end{array}$ & $\begin{array}{r}-0.0034 \\
-1.49\end{array}$ & $\begin{array}{r}0.0000 \\
-0.01\end{array}$ \\
\hline Expense Ratio & $\begin{array}{r}-1.0473 \\
-2.40\end{array}$ & $\begin{array}{r}-0.7625 \\
-1.84\end{array}$ & $\begin{array}{r}-0.2419 \\
-0.40\end{array}$ & $\begin{array}{r}-1.0069 \\
-1.05\end{array}$ & $\begin{array}{r}-0.4085 \\
-1.17\end{array}$ & $\begin{array}{r}-0.9899 \\
-2.76\end{array}$ & $\begin{array}{r}-1.2223 \\
-2.22\end{array}$ & $\begin{array}{r}-1.4423 \\
-1.79\end{array}$ \\
\hline Turnover & $\begin{array}{r}-0.0020 \\
-1.73\end{array}$ & $\begin{array}{r}-0.0008 \\
-0.71\end{array}$ & $\begin{array}{r}-0.0043 \\
-2.69\end{array}$ & $\begin{array}{r}-0.0038 \\
-1.40\end{array}$ & $\begin{array}{r}-0.0009 \\
-0.81\end{array}$ & $\begin{array}{r}-0.0012 \\
-1.31\end{array}$ & $\begin{array}{r}-0.0049 \\
-4.11\end{array}$ & $\begin{array}{r}-0.0057 \\
-2.44\end{array}$ \\
\hline Return(Past12mo.) & $\begin{array}{r}-0.0342 \\
-1.19\end{array}$ & $\begin{array}{r}0.0044 \\
0.16\end{array}$ & $\begin{array}{r}-0.0527 \\
-0.94\end{array}$ & $\begin{array}{r}-0.0259 \\
-0.39\end{array}$ & $\begin{array}{r}-0.0355 \\
-1.32\end{array}$ & $\begin{array}{r}-0.0056 \\
-0.23\end{array}$ & $\begin{array}{r}-0.0927 \\
-2.37\end{array}$ & $\begin{array}{r}-0.0796 \\
-1.32\end{array}$ \\
\hline ReturnVolatility(Past12mo.) & $\begin{array}{r}-0.5215 \\
-3.97\end{array}$ & $\begin{array}{r}-0.4147 \\
-2.81\end{array}$ & $\begin{array}{r}0.3535 \\
1.61\end{array}$ & $\begin{array}{r}-0.1935 \\
-0.60\end{array}$ & $\begin{array}{r}-0.5946 \\
-4.26\end{array}$ & $\begin{array}{r}-0.3929 \\
-3.17\end{array}$ & $\begin{array}{r}-0.2620 \\
-1.29\end{array}$ & $\begin{array}{r}-0.5887 \\
-1.87\end{array}$ \\
\hline Intercept & $\begin{array}{r}0.0618 \\
3.64\end{array}$ & $\begin{array}{r}0.0174 \\
0.96\end{array}$ & $\begin{array}{r}-0.0368 \\
-1.11\end{array}$ & $\begin{array}{r}-0.0444 \\
-0.89\end{array}$ & $\begin{array}{r}0.0548 \\
3.25\end{array}$ & $\begin{array}{r}0.0357 \\
2.45\end{array}$ & $\begin{array}{r}0.0205 \\
0.76\end{array}$ & $\begin{array}{r}0.0232 \\
0.54\end{array}$ \\
\hline $\begin{array}{l}O b s \\
A d j . R^{2}\end{array}$ & $\begin{array}{r}357 \\
0.349\end{array}$ & $\begin{array}{r}357 \\
0.031 \\
\end{array}$ & $\begin{array}{r}356 \\
0.100 \\
\end{array}$ & $\begin{array}{r}356 \\
0.082\end{array}$ & $\begin{array}{r}357 \\
0.047 \\
\end{array}$ & $\begin{array}{r}357 \\
0.061 \\
\end{array}$ & $\begin{array}{r}356 \\
0.058\end{array}$ & $\begin{array}{r}351 \\
0.029\end{array}$ \\
\hline$p$-values from Wald tests of & ce between & icate & ficie & imate & & & & \\
\hline $\begin{array}{l}\text { Gold-Silver } \\
\text { Gold-Bronze } \\
\text { Silver-Bronze }\end{array}$ & $\begin{array}{l}0.657 \\
0.007 \\
0.001\end{array}$ & $\begin{array}{l}0.772 \\
0.249 \\
0.088\end{array}$ & $\begin{array}{l}0.671 \\
0.351 \\
0.598\end{array}$ & $\begin{array}{l}0.320 \\
0.146 \\
0.476\end{array}$ & $\begin{array}{l}0.759 \\
0.142 \\
0.063\end{array}$ & $\begin{array}{l}0.965 \\
0.155 \\
0.082\end{array}$ & $\begin{array}{l}0.744 \\
0.867 \\
0.840\end{array}$ & $\begin{array}{l}0.876 \\
0.336 \\
0.231\end{array}$ \\
\hline
\end{tabular}




\section{Table 8: Calendar Time Portfolio Returns and Analyst Ratings Initiations}

Shown below are calendar time portfolio returns to portfolios formed on initial analyst ratings over the period September 2011 to December 2012. Portfolio returns are computed within each initial analyst rating group as the equal-weighted average of all funds that had previously received that initial rating type. For example, the March 2012 Gold portfolio return is the equal weighted average return (in March) of all funds that received a Gold initial rating prior to March 2012. G-S is time-series average of the difference between returns to the Gold and Silver portfolios over the sample period. Panel A results are based on raw returns. In Panel B the monthly return series is computed using match-adjusted portfolio returns. In each panel we report the mean return, market model alphas (MMAlpha), Fama and French 3-factor alphas (FF3Alpha), and Fama and French 3-factor + Momentum 4-factor alphas (FF4Alphas). T-statistics reported below coefficient estimates are based on Newey West standard errors .

\begin{tabular}{|c|c|c|c|c|c|c|c|}
\hline \multicolumn{8}{|c|}{ Panel A: Portfolio Returns } \\
\hline & Gold & Silver & Bronze & Not Rec. & G-S & G-B & G-NR \\
\hline Mean Return & $\begin{array}{r}0.0167 \\
1.93\end{array}$ & $\begin{array}{r}0.0201 \\
1.84\end{array}$ & $\begin{array}{r}0.0181 \\
1.74\end{array}$ & $\begin{array}{r}0.0129 \\
1.29\end{array}$ & $\begin{array}{r}-0.0034 \\
-1.24\end{array}$ & $\begin{array}{r}-0.0013 \\
-0.66\end{array}$ & $\begin{array}{r}-0.0014 \\
-0.55\end{array}$ \\
\hline MM Alpha & $\begin{array}{r}-0.0017 \\
-0.77\end{array}$ & $\begin{array}{r}-0.0018 \\
-0.76\end{array}$ & $\begin{array}{r}-0.0023 \\
-1.75\end{array}$ & $\begin{array}{r}-0.0017 \\
-1.10\end{array}$ & $\begin{array}{r}0.0001 \\
0.07\end{array}$ & $\begin{array}{r}0.0006 \\
0.42\end{array}$ & $\begin{array}{r}0.0009 \\
0.95\end{array}$ \\
\hline FF3 Alpha & $\begin{array}{r}-0.0020 \\
-1.18\end{array}$ & $\begin{array}{r}-0.0015 \\
-1.09\end{array}$ & $\begin{array}{r}-0.0017 \\
-1.13\end{array}$ & $\begin{array}{r}-0.0007 \\
-0.47\end{array}$ & $\begin{array}{r}-0.0005 \\
-0.34\end{array}$ & $\begin{array}{r}-0.0003 \\
-0.18\end{array}$ & $\begin{array}{r}-0.0004 \\
-0.28\end{array}$ \\
\hline FF4 Alpha & $\begin{array}{r}-0.0008 \\
-0.41 \\
\end{array}$ & $\begin{array}{r}-0.0024 \\
-1.35 \\
\end{array}$ & $\begin{array}{r}-0.0004 \\
-0.32 \\
\end{array}$ & $\begin{array}{r}0.0050 \\
7.19 \\
\end{array}$ & $\begin{array}{r}0.0016 \\
1.12 \\
\end{array}$ & $\begin{array}{r}-0.0004 \\
-0.27 \\
\end{array}$ & $\begin{array}{r}-0.0041 \\
-2.71 \\
\end{array}$ \\
\hline \multicolumn{8}{|c|}{ Panel B: Match-Adjusted Portfolio Returns } \\
\hline & Gold & Silver & Bronze & Not Rec. & G-S & G-B & G-NR \\
\hline Mean Return & $\begin{array}{r}-0.0002 \\
-0.12\end{array}$ & $\begin{array}{r}-0.0066 \\
-1.00\end{array}$ & $\begin{array}{r}-0.0019 \\
-0.99\end{array}$ & $\begin{array}{r}0.0005 \\
0.93\end{array}$ & $\begin{array}{r}0.0065 \\
1.01\end{array}$ & $\begin{array}{r}0.0017 \\
0.74\end{array}$ & $\begin{array}{r}-0.0003 \\
-0.17\end{array}$ \\
\hline MM Alpha & $\begin{array}{r}0.0017 \\
1.91\end{array}$ & $\begin{array}{r}-0.0008 \\
-0.23\end{array}$ & $\begin{array}{r}-0.0025 \\
-1.07\end{array}$ & $\begin{array}{r}-0.0001 \\
-0.11\end{array}$ & $\begin{array}{r}0.0025 \\
0.61\end{array}$ & $\begin{array}{r}0.0041 \\
1.65\end{array}$ & $\begin{array}{r}0.0017 \\
1.59\end{array}$ \\
\hline FF3 Alpha & $\begin{array}{r}0.0016 \\
2.19\end{array}$ & $\begin{array}{r}-0.0013 \\
-0.26\end{array}$ & $\begin{array}{r}-0.0034 \\
-0.99\end{array}$ & $\begin{array}{r}0.0000 \\
-0.03\end{array}$ & $\begin{array}{r}0.0029 \\
0.54\end{array}$ & $\begin{array}{r}0.0050 \\
1.48\end{array}$ & $\begin{array}{r}0.0015 \\
1.39\end{array}$ \\
\hline FF4 Alpha & $\begin{array}{r}0.0007 \\
0.82\end{array}$ & $\begin{array}{r}0.0071 \\
2.54\end{array}$ & $\begin{array}{r}-0.0025 \\
-0.89\end{array}$ & $\begin{array}{r}0.0007 \\
1.94\end{array}$ & $\begin{array}{r}-0.0064 \\
-2.22\end{array}$ & $\begin{array}{r}0.0032 \\
1.07\end{array}$ & $\begin{array}{r}-0.0012 \\
-0.84\end{array}$ \\
\hline
\end{tabular}

